Article

\title{
Gaps and Research Demand for Sustainability Certification and Standardisation in a Sustainable Bio-Based Economy in the EU
}

\author{
Stefan Majer ${ }^{1, *(\mathbb{D})}$, Simone Wurster ${ }^{2}$, David Moosmann ${ }^{1}$, Luana Ladu ${ }^{2}$, Beike Sumfleth ${ }^{1}$ \\ and Daniela Thrän ${ }^{1,3}$ \\ 1 Deutsches Biomasseforschungszentrum (DBFZ), Leipzig 04347, Germany; david.moosmann@dbfz.de (D.M.); \\ Beike.Sumfleth@dbfz.de (B.S.); daniela.thraen@ufz.de (D.T.) \\ 2 Technische Universität Berlin (TU Berlin), Berlin 10623, Germany; simone.wurster@tu-berlin.de (S.W.); \\ luana.ladu@tu-berlin.de (L.L.) \\ 3 Helmholtz Centre for Environmental Research (UFZ), Leipzig 04318, Germany \\ * Correspondence: stefan.majer@dbfz.de; Tel.: +49-341-2434-411
}

Received: 29 April 2018; Accepted: 10 July 2018; Published: 13 July 2018

\begin{abstract}
The concept of the bio-based economy has gained increasing attention and importance in recent years. It is seen as a chance to reduce the dependency on fossil resources while securing a sustainable supply of energy, water, and raw materials, and furthermore preserving soils, climate and the environment. The intended transformation is characterized by economic, environmental and social challenges and opportunities, and it is understood as a social transition process towards a sustainable, bio-based and nature-oriented economy. This process requires general mechanisms to establish and monitor safeguards for a sustainable development of the bio-based economy on a national and EU level. Sustainability certification and standardisation of bio-based products can help to manage biogenic resources and their derived products in a sustainable manner. In this paper, we have analysed the current status of sustainability certification and standardisation in the bio-based economy by conducting comprehensive desktop research, which was complemented by a series of expert interviews. The analysis revealed an impressive amount of existing certification frameworks, criteria, indicators and applicable standards. However, relevant gaps relating to existing criteria sets, the practical implementation of criteria in certification processes, the legislative framework, end-of-life processes, as well as necessary standardisation activities, were identified which require further research and development to improve sustainability certification and standardisation for a growing bio-based economy.
\end{abstract}

Keywords: bio-based economy; sustainability; certification; standardisation; sustainability criteria; gaps; sustainability assessment

\section{Introduction}

The bio-based economy (BBE) is seen as a chance to supersede the era of fossil resources and technologies, to foster health and nutrition of a growing world population, and to secure a sustainable supply of energy, water, and raw materials, while preserving soils, climate and the environment [1]. The intended transformation is characterized by economic, environmental and social challenges and opportunities, and it is understood as a social transition process towards a sustainable, bio-based and nature-oriented economy. Currently, more than 40 countries have defined specific strategies for the development of a BBE or the bioeconomy (BE) [2]. Even though there is a slight difference between the two terms BBE and BE, both concepts are often used synonymously in the literature [3]. For the 
purpose of this study, we refer to the concept of the BBE as defined by the EU, which suggests that a "bio-based economy integrates the full range of natural and renewable biological resources-land and sea resources, biodiversity and biological materials (plant, animal and microbial), through to the processing and the consumption of these bio-resources" [4]. Management and control of the intended transitions needs appropriate measurement, information, and tools to cover not only the BE as a whole, but also the different dimensions of BE development [5]. This requires general mechanisms to establish and monitor safeguards for a sustainable development of the BBE economy on a national and EU level.

Sustainability certification of bio-based products can help to manage biogenic resources and their derived products in a sustainable manner. The development and use of sustainability assessment schemes for bio-based products which contribute to a clear and evidence-based view of the economic, social and environmental impact/benefits of bio-based solutions is, therefore, an important goal in current research activities.

The concept of sustainable resource management was originally developed for the organization of forestry resources [6]. The management concepts tried to ensure that extraction of timber did not surpass regenerative capacity; thus, future generations can benefit from the forests the same way the present generation does [7]. It is not surprising that the beginnings of sustainability certification, which started by the end of last century, are also related to forest management systems. Additionally, as described by [8], early sustainability certification activities are described for agricultural production processes. To fight global deforestation and especially the destruction of native forests in the tropics and subtropics, the Forest Steward Ship Council ${ }^{\circledR}\left(\mathrm{FSC}^{\circledR}\right)$ was founded in 1993. Starting with the certification of forest management, the certification was expanded stepwise to the whole supply chain of products, including transportation steps and processing of biomass, but also to biomass resources outside the forests. This so-called chain of custody certification provided a basis for sustainability certifications for all kinds of lignocellulosic and non-lignocellulosic biomass-based supply chains. This enables complete traceability of the biomass, because each supply chain element is subject to certification. FSC ${ }^{\circledR}$ has become very successful. As of today, there are more than 200 million ha of forests certified globally and until now 33,829 chain of custody certificates were issued [9]. Although this number seems to be significant, it represents only ca. $5 \%$ of the global forest area. Nonetheless, there is an increasing demand for FSC ${ }^{\circledR}$ certified materials and products. FSC ${ }^{\circledR}$ certified products and materials have become a standard in some industries. In any case, sustainability certification has reached a stage at which it is being officially accepted to ensure the implementation of sustainability requirements laid down in laws and regulations [10]. There are, for instance, Green Public Procurement requirements that include forest certification according to internationally recognised schemes (e.g., FSC $^{\circledR}$ and PEFC ${ }^{\mathrm{TM}}$ ) as a proof of fulfilment of sustainability criteria.

The EU biofuel market is a good example of a regulated market with binding sustainability requirements based on EU legislation (i.e., [11]). As a reaction to intense debate about the possible impact of national and international biofuel policies (e.g., the 10\% target of the Renewable Energy Directive (RED)) on price increases of agricultural commodities [12] or land use changes ([13], legally binding sustainability criteria for liquid biofuels and bioliquids were developed and were, since 2009, implemented in the RED). The mandatory sustainability criteria included in this directive are mainly limited to environmental criteria. Economic or social criteria are not included, mostly because of the existing EU background regulations and potential conflicts with WTO regulations in case they would be applied outside the EU [14]. The main goal of the implementation of the RED criteria is (1) to prevent that areas with high ecological value or high carbon stocks are converted to agricultural areas dedicated to the cultivation of crops used for biofuel production; and (2) that a certain GHG emission saving from biofuels in comparison to the use of fossil fuel is ensured. An expansion of the sustainability criteria from liquid biofuels to all sectors of bioenergy including heat and power production from solid, liquid and gaseous biomass from 2021 is under discussion [15]. Currently, each market actor along the supply chain of biofuels, for example, biomass producers, traders, processors, biofuel refineries, petroleum companies, etc., must fulfill the mandatory sustainability requirements of the RED. To show 
compliance with the criteria, market actors have to obtain a certificate. The European Commission has officially recognized a number of so-called voluntary schemes for that purpose. The respective schemes differ according to the applicability concerning the geographic and feedstock scope as well as the parts of the supply chain elements being covered. Furthermore, the criteria and indicators used by sustainability certification schemes in the EU BBE can vary significantly. Mostly, the topics and even more the criteria and indicators covered by the various schemes do not reflect the complete and holistic understanding of the sustainability concept, covering social, economic and environmental impacts. Instead, the currently available certification schemes are often the result of stakeholder processes. Consequently, the criteria and indicators included represent the individual perception of the stakeholders involved regarding the relevance of certain criteria and indicators regarding the sustainability of the products to be certified. Furthermore, effective sustainability certification activities are often embedded in a specific regulatory framework, which can already set standards regarding specific sustainability requirements (e.g., EU labour rights conditions, cross compliance regulations, etc.) [16]. After a few years in operation, especially the more advanced schemes were revised and further developed. In addition, their scope was extended to applications and products beyond liquid biofuels (e.g., solid biofuels, bioplastics, biochemicals, etc.).

While the current sustainability certification activities (e.g., in the context of the RED) are focused mainly on environmental and social aspects, product standardisation supports market implementation by reducing economic hurdles [17]. Both tools (certification and standardisation) can play an important role in enabling the existing regulatory system to adapt and support innovation [18]. Based on the EU mandate M/429 from 2008, the European Committee for Standardization (CEN) established a standardisation programme for bio-based products. Consequently, CEN's Technical Committee (TC) 411 was created in 2011. Its scope comprises horizontal aspects of the BBE, including a common terminology, methods for determining bio-based content in a product, Life Cycle Assessments (LCA), sustainability of biomass and guidance on the use of existing standards for the end-of-life (EOL) options. Based on the European standardisation Mandates M/491 [19] and M/492 [20], TC 411 has been developing standards to help specific sectors move towards higher renewable biomass content.

In addition, other CEN TCs deal with specific bio-based products and applications. For example, TC 249 is responsible for the development of standards for biopolymers and TC 19 is tasked with creating standards for bio-based lubricants [21], while CEN/TC 383 works on European standards establishing sustainability criteria for biofuels. This standardisation work relates to relevant legislation supporting the development of sustainable bioenergy [11,22].

The development of harmonized and vertical standards for the BBE on an EU level will support the future sustainability of the sector despite the many challenges that still exist [17]. Nevertheless, observers have called for more advanced tools for conducting sustainability assessments of bio-based products [17]. The goal is to better demonstrate both bio-based products potential to solve important sustainability challenges and reduce concerns about possible negative implications [17].

The existing certification schemes and standardisation approaches provide a contribution to the establishment of the EU BBE. However, it is difficult to identify, if these approaches cover the different aspects of sustainability that influence consumption decisions. With a growing BBE, these aspects will become more and more important (e.g., [23]). Therefore, this paper aims to provide a systematic identification of potential gaps in terms, for example, of important aspects not covered by existing sustainability certification and standardisation tools within the EU BBE and come up with a set of first recommendations to overcome these gaps. The results presented were developed as part of the EU-funded H2020 research project STAR-ProBio.

\section{Materials and Methods}

Our analysis of existing sustainability certification and standardisation activities was based on a threefold approach. Firstly, we conducted a comprehensive analysis of existing sustainability assessment activities in different sectors of the BBE. This included the development of a general 
understanding regarding the frequency and market penetration of the various sustainability criteria used by certification frameworks, as well as the identification of differences between sectors of the EU BBE. Secondly, a series of interviews with experts (policy makers, policy advisers, scientists, certification schemes, certification bodies) were conducted to identify mega-trends regarding current and future gaps in sustainability certification. Thirdly, the comprehensive overview of criteria and indicators which was generated with the first approach was used to verify and generalise the trends and opinions which were formulated during the interviews.

\subsection{Analysis of Existing Sustainability Certification Schemes, Labels, and Initiatives in the EU Bio-Bio-Based Economy}

This analysis was conducted in three steps. Firstly, sustainability frameworks (the expressions framework and system are used synonymously in this context), with a focus on the EU BBE, were identified by desktop research and by using available databases such as Standards Map and Label Online (a). Secondly, the selected relevant frameworks were analysed to build an inventory of the sustainability criteria and indicators used in current sustainability certification (b). Thirdly, relevant standardisation activities were analysed (c).

During the first step, which aimed to picturise the sustainability frameworks presently available for application within the BBE, a preliminary list was generated. This process followed a three-stage course of action, which is illustrated in Figure 1. During steps one and two, a desktop research using web databases (ITC Standards Map, Label Online) was used to identify frameworks relevant for the BBE. With this approach, we could identify $\sim 100$ existing sustainability certification frameworks with relevance for the BBE.

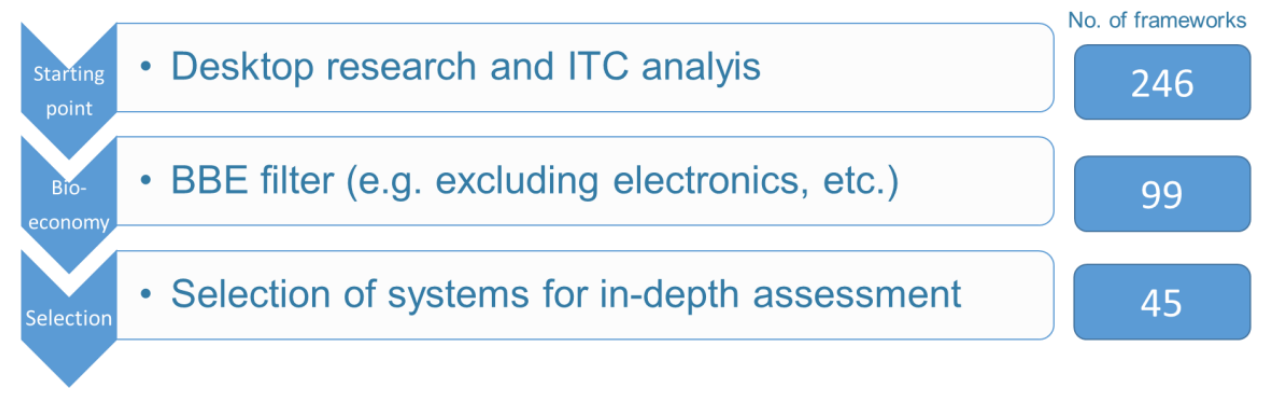

Figure 1. Analysis of relevant frameworks currently available for application in EU BBE-procedure.

The resulting list of frameworks was supplemented by a review of scientific literature. A simple database spreadsheet was produced to allow for a first characterisation (e.g., with regards to parameters such as: regional focus, product focus, sectors of the BBE covered by the framework, etc.) of the identified certification frameworks. In the final step, based on a set of criteria, the sample was reduced by half, in order to make an in-depth analysis of the frameworks feasible. For this purpose, the following criteria were determined among STAR-ProBio project partners: Scope of the certification framework, overall transparency of the system (in terms of accessibility of all relevant system documents and publication of certificate holders), comprehensiveness relating to the three sustainability dimensions (environmental, social, and economic), relevance of the framework (in terms of number of issued certificates).

The described procedure resulted in a list of sustainability frameworks for further elaboration. The frameworks were arranged within a table (see Figure 5) that includes information on the kind of framework (label, initiative, scheme, please see Table 1 for a set of working definitions), the BBE sector addressed, the supply chain coverage (single supply chain elements, full supply chain, etc.), the geographic scope (national, global), the feedstock scope (some frameworks are limited to certain feedstock or feedstock groups), and the sustainability dimension (social, environmental, economic) addressed. 
Table 1. Definition of the different types of frameworks included in the analysis.

\begin{tabular}{ll}
\hline Framework & Definition \\
\hline Labels & Labels communicate the guarantee of certain product characteristic to the consumer, \\
& which ideally is described in an adequate level of transparency. A certification process can be a \\
precondition for the labelling of a product. However, there are products self-labelled by the \\
producer. \\
Sustainability initiatives are herein referred to as initiatives compiling sets of sustainability \\
criteria and indicators for a particular purpose. They might be organised as a heterogeneous \\
group of people with different background and with different interests. The goal of this type \\
of initiative is to reach a consensus between the different parties. In the resulting set of criteria, \\
the different interests are reflected. This type of initiative is often referred to as \\
"multi-stakeholder initiative" or "roundtable". The second type of initiative considered is \\
consisting of a group of people belonging to one party. They can have a varying backgrounds \\
and interests. The one objective, quality sustainability initiatives have in common is the \\
outcome/product, which is a set of criteria for further unspecified or specified use. \\
The outcome can be used internally, e.g., for the sustainability strategy of an organisation or \\
may be picked up by others. \\
Initiatives \\
Certification schemes are based on a normative framework. The output of initiatives may be \\
used as the basis for a certification scheme. Sustainability initiatives therefore sometimes turn \\
into a certification scheme holder over time as it happened with different roundtables. \\
The most important characteristic of a certification scheme, as it is understood in this context, \\
is that it includes a third-party verification of the sustainability criteria, stipulated in the \\
system documents. Also, the whole certification process is usually based on accreditation \\
standards (e.g., ISO 19011 or ISO 17065), in which the separation of evaluation and \\
certification is to mention an important feature. As a result of the certification process, a label \\
on a product shows compliance with the respective certification scheme.
\end{tabular}

During this in-depth analysis, an inventory of the sets of criteria and indicators from the selected certification frameworks was developed (please see [24]). Since criteria and indicator sets are often adjusted and revised frequently by the certification frameworks, the latest versions of the core system documents were obtained for each framework. The inventory database which was developed throughout this process can be considered some kind of meta-standard including all criteria and indicators identified from the analysis. Since criteria and indicators are named and defined quite differently between the various frameworks, it was necessary to harmonise and structure the criteria and indicator sets. For this purpose, firstly the sustainability criteria and (if applicable) respective indicators were isolated from each framework. Gradually, terminology was harmonised and the criteria and respective indicators were organised according to the three sustainability dimensions (i.e., environmental, social and economic).

The assignment of criteria to the three dimensions of sustainability was done using a hierarchic structure with thematic categories and main principles summarising different criteria and their respective indicators (for an example, please see Figure 2). This was a necessary step to reach a point at which a manageable compilation could be formed out of the multitude of criteria of the analysed frameworks. Furthermore, several frameworks express equal criteria in slightly different ways, at different levels of detail or aggregation. In addition, a differentiation between criteria and indicators was not given for every framework analysed, due to the very diverse presentations of criteria sets in the available system documentation. The final database [24] allows tracing back the original, more detailed wording of a certain criteria. 


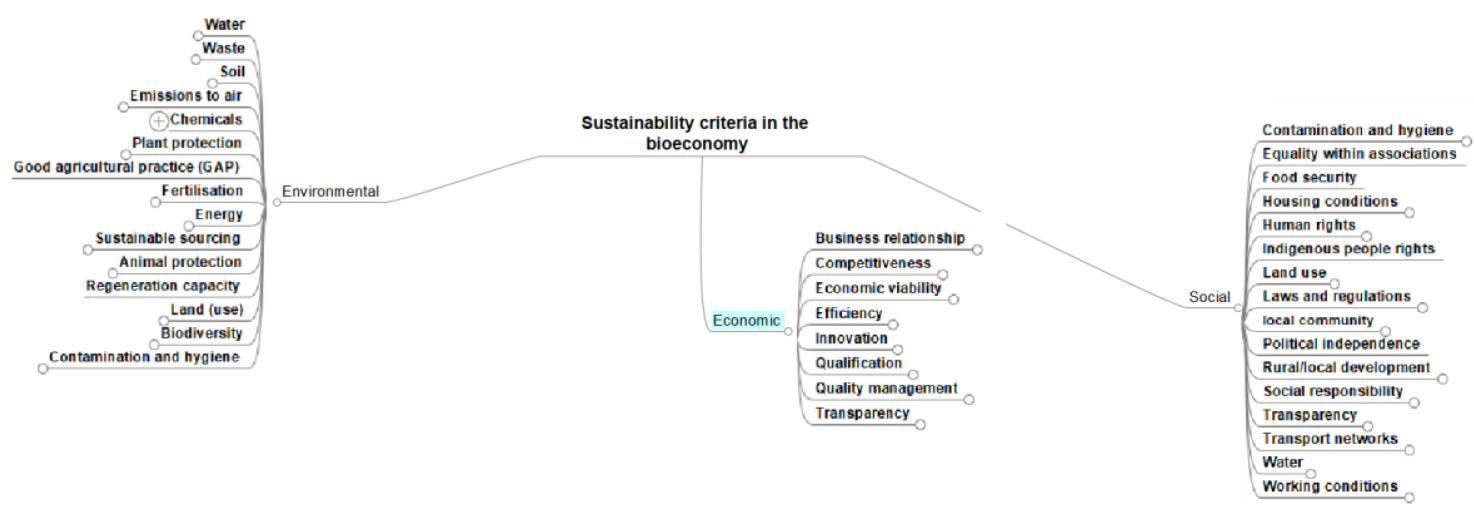

Figure 2. Example of criteria list generated from the analysis of sustainability certification frameworks.

\subsection{Expert Interviews}

To complement the detailed analysis of the framework documents, we conducted a number of interviews with experts from industry, science, policy making, standardisation and certification bodies, as well as non-governmental organizations. The main objective of these interviews was to develop a better understanding of the current discussion regarding the status of sustainability certification and standardisation in the EU BBE. Furthermore, the individual feedback received during the expert interviews provided valuable insights into the expert's perceptions of the relevance of specific topics. The points mentioned by the experts were discussed and checked against the results from the analysis of existing sustainability certification frameworks and standardisation activities.

The selection of interviewees followed principles of the grounded theory approach: theoretical sampling and theoretical saturation. According to [25], theoretical sampling uses samples that are relevant for a given research question based on individual selections. The sampling must be carried out until theoretical saturation is reached, i.e., until no new or significant information seems to appear in relation to the relevant questions. Following this approach, and under consideration of the available project resources, 25 experts were identified for interviews. In the context of our research, it was important to receive input from experts with a general expertise regarding bio-based products and sustainability certification and standardisation. In most cases, these persons belong to research institutes or universities—for example, professors—or they work as experts at European organisations. Additionally, we wanted to learn more about the specific views of producers and consumers, as well as those of representatives of standardisation and certification bodies. Experts from various European countries were selected. They represent the above-mentioned high-level experts for bio-based products, as well as producers of bio-based products, consumers, and members of standardisation committees.

Following the above-mentioned concept [25], a sampling series is finished if a repetition of the answers is experienced and the extent of new information based on additional samples is low. These repetitions could be experienced, for example, regarding the suggestions to learn from specific other standards and to adopt the good practice of the RED with certain modifications for bio-based products as well. However, specific questions on standardisation issues beyond the scope of these interviews remained, requiring specific information exchanges with representatives of standardisation TCs. In total, 20 interviews were conducted in the first interview series. It is clear that this cannot necessarily be considered a fully representative sample size. Furthermore, it is possible that the focus of the discussion points mentioned during the interviews could differ with a different proportional distribution of the stakeholder groups represented by the experts. More research is recommended to deepen our results and/or to derive new conclusions. Regarding specific standards issues, an additional series of information exchange activities with experts was conducted, based on specific questions, see Section 2.3.

The 20 interviews were conducted using a standardised questionnaire (see Appendix B). Figures 3 and 4 provide impressions regarding the background of the experts, interviewed during the 
process of gap assessment. It is important to note that the total number differs between the two figures. The reason for this is that a couple of experts gave multiple answers regarding their background and associated stakeholder group.

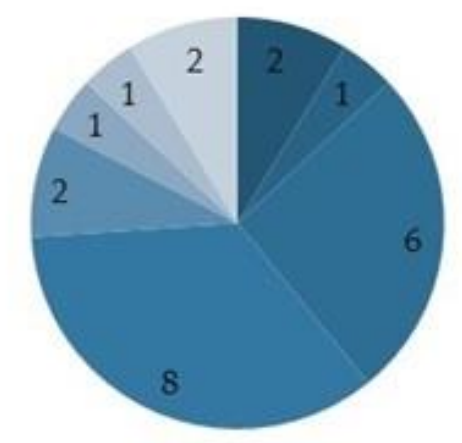

- Producer, retailer etc.

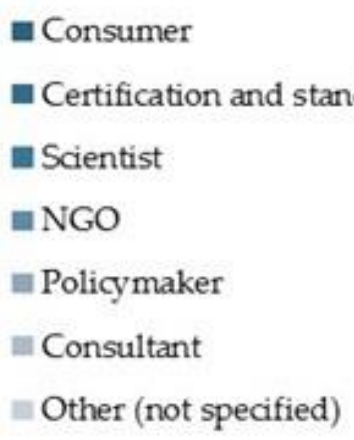

Figure 3. Stakeholder group of the interviewed experts and their mentioned amount (multiple responses allowed).

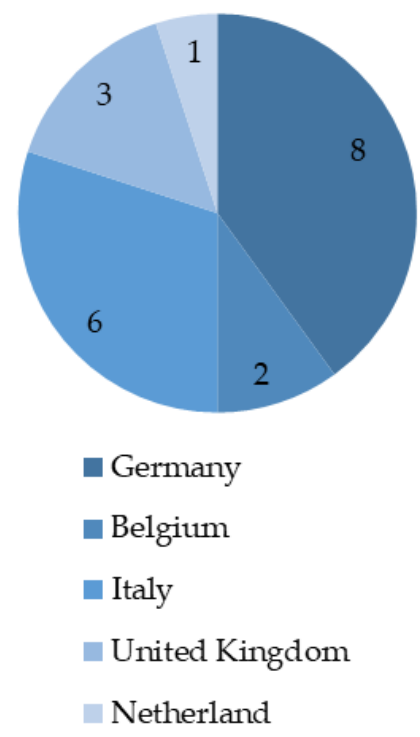

Figure 4. Country of origin of the interviewed experts and their mentioned amount.

\subsection{Analysis of Existing Sustainability Standards in the EU Bio-Based Economy}

In addition to the analysis in the field of sustainability certification, the focus of the third analytical step was on existing sustainability standards for bio-based products and standards in related areas. The database Perinorm (https:/ /www.perinorm.com) and relevant documents were analysed for this 
purpose using 22 keywords. Perinorm contains approximately two million records of the European and global key facts on standards, technical regulations and legislation. It includes documents from the European and international standards bodies, the European Committee for Standardization (CEN), the European Committee for Electrotechnical Standardization (CENELEC), the European Telecommunications Standards Institute (ETSI), the International Organization for Standardization (ISO), the International Electrotechnical Commission (IEC) and the International Telecommunication Union (ITU), as well as those from standard bodies in Japan, China, USA, Jordan, South Africa, Canada, and Brazil. Based on the results obtained, more specific information can be obtained regarding the classification (type of standard, industry), document maturity (draft standards, standards etc.), valid records, country of origin and relation to European and international standards. Table 2 shows keywords used for the Perinorm search. Search results were further specified. For example, entries in the following fields were deleted: sustainable tourism, tractors, and machinery for agriculture and forestry, aluminium structures and electronic signatures. Several standards on environmental management, such as JS 14040 and JIS Q 14040, were also deleted, because both refer to the ISO standard with the same name.

Table 2. Keywords of the Perinorm search.

\begin{tabular}{cccccc}
\hline Keyword & Total & Keyword & Total & Keyword & Total \\
\hline algae products & 75 & biofuel & 94 & life cycle assessment & 1046 \\
animal-based & 3 & biofuels & 1.527 & plant-based & 30 \\
bio-based & 60 & biomass & 1.420 & starch-based & 1 \\
bio-based & 300 & bioplastics & 27 & sustainability & 3361 \\
biochemicals & 290 & cellulose-based & 95 & sustainable & 487 \\
biodegradable & 445 & end-of-life & 410 & value chain & 65 \\
biodiesel & 283 & footprint & 126 & & \\
bioenergy & 16 & forest products & 88 & & \\
\hline
\end{tabular}

Considering the importance of the issues of direct and, in particular, indirect land use change (iLUC) related to the sustainability of bio-based materials and bioenergy (see, e.g., [26]), three additional terms were analysed afterwards. For the term "indirect land use change" and its abbreviation "ILUC", no results were obtained. On the other hand, the term "land use change" led to 17 hits, and to the identification of a relevant international standard; the latter was analysed in greater detail: ISO 13065 [27]. In addition to this, four national standards that deal with this topic [28-31] were identified. Due to the low number of results, the suitability of an additional search term "land use" was analysed. On the European and international level, the search for valid standards led to 153 hits. However, most of them were focused on other areas, such as agricultural machinery, tractors, etc., and were not relevant for the purpose of this assessment. Exemptions are EN 16214-4 and ISO 14055-1. The Perinorm results were further analysed, screened and clustered to get deeper insight in the current standards landscape of bio-based products (see Tables A13 and A14 in Appendix D).

Our paper aims at addressing the need for more advanced tools for conducting sustainability assessments by integrating its work appropriately in this existing standardisation landscape. For that reason, not only experts for bio-based products in general, but also experts from the field of standardisation were interviewed. Thirteen European and international TCs and PCs (Project Committees) were identified as relevant for this work. In particular, attention was drawn to three technical committees: CEN/TC 411-Bio-based products, ISO/TC 207-Environmental management and ISO/PC 248-Sustainability Criteria for Bioenergy. 


\section{Results}

\subsection{Overview on Existing Certification Frameworks}

Existing activities regarding sustainability certification in the EU BBE can differ significantly with regard to their operability, stakeholder involvement, scope, etc. To allow for a differentiation, we have distinguished three types of sustainability frameworks (for our working definitions please see Table 1): (a) labels, (b) sustainability initiatives, and (c) certification schemes.

Analysing the currently existing sustainability certification activities in the EU BBE, we found a broad range of existing certification frameworks addressing different sectors, and scopes regarding feedstocks, the completeness of the supply chain as well as coverage of geographic areas. Figure A1 gives a wide overview of available sustainability certification frameworks in the EU BBE. Figure 5 provides a summary of the frameworks selected for an in-depth assessment during our analysis. Additional information can be found in Appendix A.

The criteria and indicators included in the analysed certification frameworks were assessed and structured into a database [24] which is available on the Homepage of the STAR-ProBio project. This collection of information allowed for a comparison between the statements made by experts (e.g., regarding criteria and indicator gaps in current sustainability certification) and the currently available certification frameworks.

\subsection{Gaps in Current Sustainability Certification Activities}

The assessment approach described under Section 3.1 revealed a number of areas with needs and demands for further research regarding assessment tools and general frameworks, as well as criteria and indicators for certification activities in the BBE.

During the interviews conducted (see Section 2.2 and Appendix C), the experts mentioned several areas of potential gaps in sustainability certification. The statements made by the experts were compared to the criteria and the inventory database which was prepared during the analysis of the existing certification frameworks (see [24]). Based on this process, we summarised the identified discussion points into seven main topics with demand for future research and development. A comprehensive overview on the expert statements received during the process and the allocation of these statements to the seven main topics is included in Appendix C, Tables A6-A12.

The main topics identified can be summarised as follows:

- Gaps and weaknesses in criteria and indicator sets

- Harmonisation in criteria assessment and operationalisation

- Legislation and consensus for minimum criteria in all BBE sectors

- Leakage effects from EU BBE policies

- New innovative, inter-sectoral products

- EOL

- Traceability of sustainability and certificates along the value chain

In the following paragraphs of this Section, we will describe the findings for each of the topics identified. 


\begin{tabular}{|c|c|c|c|c|c|c|c|c|c|c|c|}
\hline & Sector & Label & Initiative & Certification & Name & Geopranhic & Scope & & Saciat & Criteria & 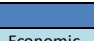 \\
\hline Bioenergy & Liquid biofuels & 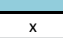 & & \begin{tabular}{|c|c|c|} 
screme \\
$x$
\end{tabular} & \begin{tabular}{|l} 
International Sustainability \& Carbon Certification (IICC) \\
\end{tabular} & 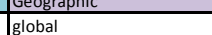 & \begin{tabular}{|l|} 
Feedstock \\
multiple
\end{tabular} & $\begin{array}{l}\text { Supply Chain } \\
\text { full }\end{array}$ & $\frac{\text { Social }}{x}$ & $\frac{\text { Environment }}{x}$ & Economic \\
\hline & & $\mathrm{x}$ & & $\mathrm{x}$ & REDcert EU & Europe (+Ukraine, Belarus) & multiple & full & $x$ & $\mathrm{x}$ & \\
\hline & & $x$ & & $x$ & Roundtable on Sustainable Biomaterials EURED (RSB EURED) & global & multiple & full & $x$ & $x$ & \\
\hline & & $\mathrm{x}$ & & $\mathrm{x}$ & Red Tractor Farm Assurance Combinable Crops \& Sugar Beet (Red Tractor) & Juk & cereals, oilseeds, sugar beet & until first feedstock delivery point & & $\mathrm{x}$ & \\
\hline & & $x$ & & $x$ & Roundtable on Sustainable Palm Oil RED (RSPO) & global & multiple & full & $x$ & $x$ & $x$ \\
\hline & & & & $x$ & Certification System adressing Indirect Impacts of Biofuel (CIIB) & EUt & multiple & farm gate to first processor & & $x$ & \\
\hline & Solid biofuels & $x$ & & $x$ & Sustainable Biomass Partnership (SBP) & global & woody biomass & $\begin{array}{l}\text { from cultivation to energy } \\
\text { production }\end{array}$ & $x$ & $x$ & $\mathrm{x}$ \\
\hline & & $x$ & & $\mathrm{x}$ & DINplus Short rotation coppice sustainably grown according to DIN EN 16214-3 & global & SRC wood & cultivation & $x$ & $\times$ & \\
\hline & & $x$ & & $x$ & Nordic Ecolabeling (SWAN) & $\begin{array}{l}\text { Denmark, Finland, lceland, } \\
\text { Norway Sweden }\end{array}$ & woody biomass & & $\mathrm{x}$ & $\mathrm{x}$ & $\mathrm{x}$ \\
\hline & Biogas & & $\begin{array}{l}x \\
x\end{array}$ & $x$ & $\begin{array}{l}\text { CIB- Biogasdoneright } \\
\text { Green Gas Certification Scheme (GGCS) }\end{array}$ & $\begin{array}{l}\text { taly } \\
\text { uk }\end{array}$ & $\begin{array}{l}\text { multiple } \\
\text { multiple }\end{array}$ & \begin{tabular}{|l} 
production process, product \\
production to use
\end{tabular} & & $\begin{array}{l}x \\
x\end{array}$ & $x$ \\
\hline & Heat/Power & & 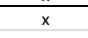 & & Global Bioenergy Partnership (GBEP) & global & multiple & & $x$ & $\mathrm{x}$ & $\mathrm{x}$ \\
\hline & & $x$ & & $x$ & nature made star & $\mathrm{CH}$ & multiple & energy production and delivery & & $x$ & \\
\hline & & $x$ & & & OK-Power & Germany & multiple & power production & & $x$ & \\
\hline & & $\begin{array}{l}x \\
x\end{array}$ & & $x$ & $\begin{array}{l}\text { Grüner-Strom-Label (Green-Power-Label) } \\
\text { Green-e }\end{array}$ & $\begin{array}{l}\text { Germany } \\
\text { global }\end{array}$ & $\begin{array}{l}\text { multiple } \\
\text { multiple }\end{array}$ & $\begin{array}{l}\text { power production to distribution } \\
\text { full }\end{array}$ & $\mathrm{x}$ & $\begin{array}{l}x \\
x\end{array}$ & $x$ \\
\hline Forestry & & $\mathrm{x}$ & & $x$ & Forest Stewardship Council (FSC) CoC & |global & woody biomass & full & $x$ & $\mathrm{x}$ & $x$ \\
\hline & & $x$ & & & Eco-Certified Composite (ECC) Sustainability Standard & USA & wood fiber & full & & $x$ & \\
\hline Construction & & $x$ & & $x$ & DGNB System & & & from cradle to grave & $x$ & $\mathrm{x}$ & $x$ \\
\hline & & $\mathrm{x}$ & & $\mathrm{x}$ & Green Building Rating System BREEAM & global & & $\begin{array}{l}\text { design and procurement stage, } \\
\text { post construction stage }\end{array}$ & $\mathrm{x}$ & $\mathrm{x}$ & $\mathrm{x}$ \\
\hline & & $\mathrm{x}$ & & & Assessment System for Sustainable Building (BNB) & Germany & & from cradle to grave & $\mathrm{x}$ & $\mathrm{x}$ & $\mathrm{x}$ \\
\hline & & $x$ & & & & Switzerland & & & & & \\
\hline & & x & & $x$ & Leadership in Energy and Environmental Design (LEED) & global & & & $x$ & $\mathrm{x}$ & \\
\hline Food & Fair Trade Certification Systems & $\bar{x}$ & & $\bar{x}$ & Fairtrade-Label - Fairtrade Labelling Organizations International (FLo) & fglobal & crops & full & $\bar{x}$ & $\bar{x}$ & $\bar{x}$ \\
\hline & & $\mathrm{x}$ & & $\mathrm{x}$ & NATURLAND fair & global & multiple & full & $x$ & $x$ & $x$ \\
\hline & & $x$ & & $\mathrm{x}$ & Rapunzel Hand in Hand & global & multiple & full & $\mathrm{x}$ & $\mathrm{x}$ & $\mathrm{x}$ \\
\hline & Fish Certification Systems & $x$ & & $x$ & Marine Stewardship Council (MSC) & global & fish & from fisheries to retailers & $x$ & $\times$ & $\mathrm{x}$ \\
\hline & Agricultural Products & $\mathrm{x}$ & & $x$ & GlobalGAP crops certification & global & crops & pre-farm-gate & &  & $\mathrm{x}$ \\
\hline & & $x$ & & $\mathrm{x}$ & demeter & global & multiple & cultivation to processing & & $\mathrm{x}$ & \\
\hline & & $x$ & & $\mathrm{x}$ & Ecovin & Germany & grapes & cultivation to processing & & $x$ & \\
\hline & & $x$ & & $x$ & Sustainable Agriculture Network/ Rainforest Alliance Certified (SAN) & global & crops & cultivation & $x$ & $x$ & \\
\hline & & $x$ & & $\mathrm{x}$ & Roundtable on sustainable palm oil (RSPO) & global & palm oil & full & $x$ & $x$ & $\mathrm{x}$ \\
\hline & & $x$ & & $x$ & uTz certified & global & coffee, cacao, tea, hazelnut & full & $\mathrm{x}$ & $x$ & $x$ \\
\hline Feed & & $x$ & & $x$ & GMP+ Feed Responsibility Assurance & global & soy, fish meal & feed production and trade & & $x$ & $x$ \\
\hline & & $x$ & $x$ & $\mathrm{x}$ & DLG certificate sustainable agriculture & Germany & multiple & agricultural production & $x$ & $\mathrm{x}$ & $\mathrm{x}$ \\
\hline Textiles & Fair Trade Certification Systems & $x$ & & $\mathrm{x}$ & Fairtrade Textile Standard - Fairtrade Labelling Organizations International (FLO) & global & $\begin{array}{l}\text { certifified cotton, other } \\
\text { responsille fibres }\end{array}$ & full & $\mathrm{x}$ & $\mathrm{x}$ & $\mathrm{x}$ \\
\hline & & $\mathrm{x}$ & & $\mathrm{x}$ & NATURLAND Textil (natureland textile) & global & natural fibre & production & & $\mathrm{x}$ & \\
\hline & & $x$ & & $\mathrm{x}$ & EU Ecolabel - fabrics & $\mathrm{EU}, \mathrm{CH}, \mathrm{NOR}, \mathrm{ISL}, \mathrm{TUR}$ & multiple & produ & $x$ & $x$ & \\
\hline & & $\frac{x}{x}$ & & $\frac{x}{x}$ & Textile Exchange Organic 100\% content standard & global & organic fibres & produ & & & \\
\hline Chemicals & & $\mathrm{x}$ & $x$ & $\mathrm{x}$ & ISCC PLUS & global & multiple & full & 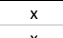 & $\mathrm{x}$ & $\mathrm{x}$ \\
\hline and Plastics & & & $x$ & & Bioplastic Feedstock alliance & global & multiple & full & $\times$ & $x$ & $x$ \\
\hline Pharmacy & Cosmetics & $x$ & & $x$ & COSMOS Standard-Cosmetics organic and natural standard & global & multiple & production process, product & & $x$ & \\
\hline Materials/ & & $\frac{x}{x}$ & & $x$ & CRADLE TO CRADLE CERTIFIED PRODUCT STANDARD & |global & multiple & production process, product & $x$ & $x$ & \\
\hline Products & & & $x$ & & $\begin{array}{l}\text { INRO Nachhaltigkeitskriterien für die stoffliche Biomassenutzung (sustainablity } \\
\text { cititerij formaterial use f biomass) }\end{array}$ & global & agricultural biomass & cultivation & $\mathrm{x}$ & $\mathrm{x}$ & $\mathrm{x}$ \\
\hline & & $x$ & & $x$ & Nature Care Products Standard & global & multiple & products & & $\mathrm{x}$ & $\mathrm{x}$ \\
\hline
\end{tabular}

Figure 5. Overview of selected existing sustainability certification frameworks. 


\subsubsection{Gaps and Weaknesses in Criteria and Indicator Sets}

It is important to mention that our analysis of certification frameworks showed an impressive list of sustainability criteria and indicators included in current sustainability certification of the EU BBE (compare [24]). The criteria and indicators available cover a wide range of sustainability aspects. While some experts stated that the future challenges for the further development of sustainability certification are not about developing more criteria and indicators, but instead the already available criteria and indicators should be used better and more frequently, another expert mentioned that there are still some gaps regarding the specific principles, criteria and indicators currently used in sustainability certification (please see Table A6) We compared the results from the expert interviews to the criteria matrix resulting from our analysis of certification frameworks to identify potential gaps. During the interviews, the work of the S2BIOM consortium was mentioned by one expert. Based on this input, we conducted a review of additional sources to be included in our assessment [32-35]).

Although our analysis and comparison of the questionnaire responses and the criteria assessment showed a wide range of criteria and indicators implemented, the following topics, criteria and indicator seem not to be significantly reflected by certification frameworks so far:

- $\quad$ Land use efficiency

- Tertiary resource efficiency (for the purpose of this paper, we followed the following categorisations: primary biomass resources as composed by plants, secondary biomass resources are related to animals/livestock production, tertiary biomass resources are related to post-consumption, post-production residues/wastes)

- Functionality (output service quality)

- (indirect) land use change GHG emissions

- $\mathrm{SO}_{2}$ equivalents

- $\mathrm{PM} 10$

- Risks for negative impacts on food prices and supply

- Levelised life-cycle cost (excluding subsidies, including CAPEX, OPEX)

- Bio-based content and recyclability/biodegradation

The development of a detailed definition or a consistent conceptual design for these topics, criteria and indicators is outside the scope of this paper; however, to support the discussion and the work in ongoing research activities, the following Table 3 includes proposals for basic definitions of the topics mentioned. 
Table 3. Characterization of identified criteria in the context of bio-based products (based on [32-35]).

\begin{tabular}{|c|c|c|}
\hline Topic/Criteria/Indicator & Definition & Nature of the Gap \\
\hline Land use efficiency & $\begin{array}{l}\text { Number of bio-based products (including by- and co-products along the life } \\
\text { cycle) per hectare of used area. }\end{array}$ & $\begin{array}{l}\text { Technical criterion, Economic criterion; related to biomass } \\
\text { production }\end{array}$ \\
\hline Tertiary resource efficiency & $\begin{array}{l}\text { Value of the bio-based output divided by the value of the secondary } \\
\text { resource. This criterion applies to bio-based products stemming from the } \\
\text { conversion of secondary biomass resources such as residues and wastes. }\end{array}$ & $\begin{array}{l}\text { Technical criterion, Economic criterion; } \\
\text { Related to by- and co-product use }\end{array}$ \\
\hline Functionality (Output service quality) & $\begin{array}{l}\text { Economic value of the outputs, compared to the economic value of the heat } \\
\text { which could be produced from burning the (dried) primary inputs. }\end{array}$ & $\begin{array}{l}\text { Economic criterion to assess or benchmark added value of a } \\
\text { specific production pathway in comparison to alternatives }\end{array}$ \\
\hline $\begin{array}{l}\text { (indirect) land use change GHG } \\
\text { emissions }\end{array}$ & $\begin{array}{l}\text { GHG emissions resulting from carbon stock changes as a direct or indirect } \\
\text { effect of feedstock production (e.g., due to the conversion of natural land } \\
\text { into cropland caused either as direct land use change or indirect land use } \\
\text { change from the production of a bio-based product). }\end{array}$ & $\begin{array}{l}\text { Environmental criterion, related to the conversion of land } \\
\text { for biomass production }\end{array}$ \\
\hline $\mathrm{SO}_{2}$ equivalents & $\begin{array}{l}\text { Life cycle emissions of } \mathrm{SO}_{2}, \mathrm{NO}_{\mathrm{x}}, \mathrm{NH}_{3} \text { and } \mathrm{HCl} / \mathrm{HF} \text { from bio-based product } \\
\text { life cycle, expressed in } \mathrm{SO}_{2} \text { equivalents and calculated in accordance to the } \\
\text { life cycle emission methodology for } \mathrm{GHG} \text {. This criterion helps to describe } \\
\text { the acidification potential of a bio-based product. }\end{array}$ & $\begin{array}{l}\text { Environmental criterion, related to upstream and } \\
\text { downstream emissions throughout the life-cycle of a } \\
\text { bio-based product }\end{array}$ \\
\hline PM10 & $\begin{array}{l}\text { Life cycle emissions of PM10 from bio-based product life cycle, calculated in } \\
\text { accordance to the life cycle emission methodology for GHG. Supports the } \\
\text { quantification of small particle emissions. }\end{array}$ & $\begin{array}{l}\text { Environmental criterion, social criterion, related mostly to } \\
\text { the conversion (combustion) of bio-based materials at the } \\
\text { end of the life cycle }\end{array}$ \\
\hline $\begin{array}{l}\text { Risks for negative impacts on food } \\
\text { prices and supply }\end{array}$ & $\begin{array}{l}\text { This criterion needs to be fully described and should consider the BEFS } \\
\text { methodology [36]. }\end{array}$ & $\begin{array}{l}\text { Social criterion, economic criterion, related to increasing } \\
\text { competition for land and biogenic resources due to an } \\
\text { increasing demand for biomass as a result of a growing BBE }\end{array}$ \\
\hline Levelised life-cycle cost & $\begin{array}{l}\text { Levelised life-cycle cost, excluding subsidies (excluding subsidies, including } \\
\text { CAPEX, OPEX). }\end{array}$ & $\begin{array}{l}\text { Economic criterion, related to the costs associated with the } \\
\text { production, utilisation as well as the EOL phase of the } \\
\text { bio-based product }\end{array}$ \\
\hline $\begin{array}{l}\text { Bio-based content and } \\
\text { recyclability/biodegradation }\end{array}$ & $\begin{array}{l}\text { The share of a product originating from biomass. } \\
\text { Percentage or share of the bio-based products that are biodegradable. }\end{array}$ & $\begin{array}{l}\text { Technical criteria, related to the production of } \\
\text { multi-compound materials as well as to EOL scenarios for } \\
\text { bio-based materials }\end{array}$ \\
\hline
\end{tabular}


It is important to mention that the certification frameworks analysed for this study were developed under specific regulations, for specific markets and applications as well as under consideration of their specific stakeholder perspectives. These influencing factors have led to individual set-ups of topics, principles and criteria included in the various certification activities. Consequently, the uptake and implementation of additional or new criteria and indicators into certification frameworks depend on a number of elements. Among others, the existing legal framework and the requirements regarding sustainability certification in the different sectors of the BBE on EU and member state (MS) level, as well as the availability of appropriate standards and tools to support the implementation, have to be considered. Furthermore, the self-conception (during our analysis we experienced significant differences regarding comprehensiveness of the criteria sets of the different frameworks analysed. While some frameworks work with sets of minimum criteria (e.g., the core sustainability criteria of the RED), others tend to frequently update and expand their criteria and indicator sets) and market positioning of the certification framework, as well as the expectations of the stakeholders involved, are additional elements that influence the possibility to add new criteria to existing certification frameworks.

\subsubsection{Harmonisation and Level Playing Field in Criteria Assessment and Operationalisation}

The second topic identified during our assessment was specifically mentioned by several of the interviewed experts (please see Table A7). It was directly mentioned by representatives of certification bodies and certification schemes that there is already an overwhelming number of sustainability criteria and indicators available. According to the interview results, the recent challenge and demand is not the development of completely new criteria and indicators, but the (a) adaptation and more precise communication of the existing ones, as well as (b) a harmonisation of the actual operationalisation of the existing criteria by the certification schemes and certification bodies. These statements are slightly contradictory compared to the topic presented in the previous section (see Section 3.2.1). Reason is mainly, that the topics were identified as relevant by experts with different backgrounds. While additional demand for research regarding criteria and indicators was mentioned mainly by experts from scientific institutions, the topic of harmonisation and a better operationalisation was brought up by representatives of certification bodies and certification frameworks.

During our analysis and the interviews, we found that, even though a number of certification frameworks cover the same principles or criteria, the methods or procedures of applying and assessing those criteria in practical audits can differ significantly between the frameworks and even between the certification bodies which conduct auditing processes on behalf of the same certification framework. This can be problematic, especially for criteria whose assessment in an actual auditing process is time or resource intense, or which can be linked to a price benefit for the certified product. An example is the calculation of the GHG mitigation threshold value for liquid biofuels in the EU market. This is a mandatory sustainability criteria under the RED framework. Since in some countries (e.g., in Germany), the outcome of the GHG mitigation threshold assessment is not only relevant for the general acceptance of a biofuel in the market, incentives such as a GHG-related biofuel quota might result in price benefits for additional GHG savings beyond the threshold value of the RED. As a consequence, there is a strong incentive for producers to optimise the GHG footprint of their biofuel. This optimisation process might also involve possibilities which do rather stem from the GHG calculation methodology itself than from an actual optimisation of the process value chain for biofuel production [37-39]. Interestingly, one would expect that especially the wide availability of detailed regulations and rules (e.g., ISO standards or the calculation framework for biofuels as defined in the EU renewable energy directive 2009/28/EC and the related communications) for the calculation of GHG mitigation effects from bio-based materials would help to harmonise the actual calculation procedure. However, even in the highly regulated (with regard to the GHG calculation rules) sector of biofuels, significant differences do exist between the different certification schemes and the certification bodies implementing the respective rules and guidelines. While the general methodology for GHG emission calculation 
(especially with regards to system boundaries, characterisation values, allocation rules, etc.), as well as comparator values for a determination of mitigation values, are clearly defined, differences in upstream emission factors or definitions of by-products or waste materials can lead to significant differences in results.

Demand for more harmonisation in the actual operationalisation of sustainability criteria and indicators seems to be relevant, mostly in business-to-business markets and sectors with a high degree of regulation (such as the biofuels sector). With the introduction of the RED, the EU commission has created a regulated market for biofuels with a set of mandatory and binding sustainability criteria. Producers of biofuels need to proof that they meet the criteria the RED criteria. Several certification frameworks were developed and recognised by the Commission since the implantation of the RED. These frameworks have implemented the RED criteria into their specific guidelines and auditing processes. However, as described above the frameworks (in this case, the frameworks addressing the biofuels sector) analysed in this study differ not only with regard to the overall comprehensiveness of their criteria and indicator sets, but also with regards to the point how the same criteria are being operationalised and implemented between the different certification frameworks. There are various examples for sustainability criteria that are applied and operationalised differently between the existing frameworks. During our expert interviews, the following criteria were explicitly mentioned in this regard:

- GHG mitigation thresholds or GHG emission calculations,

- the definition and implementation of core labour standards (e.g., based on ILO principles),

- Guarantee of no deforestation after a certain cut-off date,

- Legality of sourcing,

- $\quad$ Land use rights.

During our interviews, especially the representatives of more advanced (basically meaning certification frameworks with more comprehensive criteria sets) certification schemes pointed out the importance of creating a level playing field with regards to the actual operationalisation of the criteria between the existing frameworks. One of the most important reasons for the existing differences in the operationalisation of criteria between certification frameworks can be found in the basic nature of the applied methodologies for criteria assessment. While a huge number of criteria sets, indicators and methods for sustainability assessment are currently available, most of these elements were developed for scientific purposes. For certification practises, they need to be simplified, robust, transparent clear and applicable even if limited data and resources are available. This means that often additional effort for a transfer of existing scientific methodologies into certification practice (often by simplifying the initial methodologies and by making them more robust and useable) is necessary. During the interviews, this was identified as one of the main barriers for the implementation of new scientific methods in the actual practice of sustainability certification. To address the gaps identified under this topic, work on the legal framework and additional guidance/recommendations regarding the technical application of the various sustainability criteria in auditing practice is necessary.

\subsubsection{Legislation and Consensus for Minimum Criteria in All BBE Sectors}

While the point regarding the harmonisation of the actual operationalisation between certification schemes can be considered a horizontal issue, which is becoming relevant especially in markets with stronger legislations regarding mandatory sustainability criteria (e.g., the EU biofuels market), another important issue mentioned was the lack of a level playing field regarding the general sustainability requirements and consequently, sustainability certification practices across the various sectors of the BBE. During the interviews, it was mentioned several times, especially by experts from policy and industry, that instead of developing new criteria, it might be more important to harmonise the existing criteria and requirements for sustainability certification across the various sectors of the BBE in the EU. One of the experts stated, for example: "it is less important to introduce additional criteria, 
it is more important to mainstream sustainability requirements to all kind of biomass production. We then might need equivalent sets for production from Agriculture, Forestry, waste management, creation in laboratories and all kinds of technical reactors, etc." (see Appendix C, Table A8 for more details). The point addressed here is different from the topic raised under Section 3.2.2. While the previous topic was basically about harmonising the understanding, interpretation and implementation of one sustainability criterion (from legislation) between different certification frameworks, the point addressed here refers to the general level of sustainability requirements and legislation across the different BBE sectors.

Currently, sustainability certification in the EU BBE is characterised by sectors with and without legally binding sustainability criteria; as a direct consequence, we can observe a number of effects such as:

- Leakage effects (compare Section 3.2.4),

- Missing compatibility between the existing frameworks (e.g., in the sense of meta-stands, i.e., sustainability certification schemes recognising on another) for certification and consequently:

- Missing harmonisation and standardisation activities.

The issue of potential leakage effects is related to topics such as indirect land use change or food security risks. The rationale behind is that due to the different regulations and the bindingness of sustainability criteria between the different sectors of the BBE, pressure, e.g., regarding land resources and hard criteria such as the definition of "no-go-areas", as under the RED it could be shifted from sectors with strong mandatory sustainability requirements in their respective field to sectors with no mandatory sustainability requirements (all sectors other than the sector of biofuels for transportation). Furthermore, these differences in the regulatory framework lead to substantial differences regarding the principles, criteria sets and indicators in certification frameworks between the various sectors of the BBE. As a consequence, compatibility and mutual acceptance between existing frameworks from different BBE sectors are often missing. This can lead to additional burdens and barriers for market actors in the BBE. While to some extent a differentiation of the certification frameworks seems to be desirable, the definition of a consensus for minimum sustainability criteria for all sectors of the BBE would be an important step to reduce negative leakage effects and unnecessary administrative burdens for market actors. Interestingly, this point was brought up especially by experts from industry and policy.

Another important aspect is that a growing BBE, with an increasing cascading use of biomass and bio-based products, might also require an increasing cross-sectoral compatibility and recognition between the different certification frameworks of the various sectors of the bio-based economy. Potential solutions to overcome this barrier are meta-standard-frameworks, which consist of certification frameworks recognising each other. This makes it possible to combine certificates from different frameworks for different parts of the value chain to receive a certification over the complete value chain based on the overarching criteria and indicators of the "meta-standard-framework" (which would be a consensus or an expression of minimum criteria recognised by all certification frameworks recognised under the meta-standard).

\subsubsection{Leakage Effects from EU BBE Policies}

The introduction of mandatory sustainability requirements in the RED has addressed a number of pressing and highly relevant sustainability issues related to a large-scale rollout of biofuels for the EU transportation sector. As a consequence, some of these pressing sustainability issues such as the conversion of land with high carbon stocks such as forests into cropland being shifted to other sectors of the bio-based economy which are not directly addressed by mandatory sustainability requirements. These leakage effects, which are related to different topics such as indirect land use change, carbon debt or food security risks are still intensively discussed in the EU bioenergy sector [12,40,41]. 
During the interviews conducted, especially experts from science and policy expressed the opinion that the future success of a BBE will largely depend on the solution of these major sustainability issues (please see Table A9). However, it seems to be widely recognised that a solution to this problem cannot be created solely and isolated out of the biofuel sector [42,43]. There seems to be a risk that, as a consequence of these unsolved issues, the general trust in the development of a sustainable BBE could be tarnished.

An actual solution to problems arising from iLUC and/or a lack of good governance and an unsustainable management of natural land resources such as forests should be based on local solutions (e.g., [42]) and could not come from certification activities, which are focussing on specific sectors and parts of BBE value chains alone. The EU commission is currently organising the negotiations for the development of a RED recast for the 2021-2030 timeframe [15]. Currently available drafts of the document indicate that the sustainability criteria implemented for liquid biofuels will be expanded to electricity and heat production based on biomass. The proposal has two main components: it focuses on limiting the maximum share of food-and-feed-based biofuels by introducing a cap and establishes a sub-target for fuels that are deemed to bring GHG reductions to the transport sector-renewable; electricity included. This is an important first step for the development of a level playing field regarding minimum sustainability criteria for all biomass uses under the EU bio-based economy. Consequently, land use implications pulled by EU BBE activities would be direct land use change implications associated with the responsible sector of the BBE.

Furthermore, recent scientific activities aimed to identify key parameters linked to risks for issues such as iLUC change or food security and to translate these parameters into criteria and indicators suitable for sustainability certification [44-48]. This can be an important step to derive applicable and specific action points to mitigate iLUC risks. While iLUC risks associated with an increasing demand for bio-based materials are often being discussed and quantified using different modelling approaches (e.g., [42,49]), mitigation measures to reduce iLUC effects on market actor level can often not be developed just based on iLUC modelling work [42]. Thus, certification activities could complement the existing research on iLUC assessment. Examples can be found in initiatives aiming at the certification of "low iLUC risk biomass" (e.g., when produced from degraded or abandoned land or from yield increases) [44-48]. Furthermore, the STAR-ProBio project has delivered results regarding the identification of key parameters driving LUC risks from BBE value chains [48]. Future activities will aim at the development of iLUC risk indicators to be used for sustainability certification.

\subsubsection{Sustainability Assessment and Certification for New Innovative, Inter-Sectoral Products}

The general perception of the BBE is to some extent characterised by an expected high potential for innovation [2,5]. New, innovative products and bio-based resources are expected to be an essential part in the future BBE. Some of these resources and products could even represent interesting links between fossil industry sectors and sectors of the bio-based economy [50,51]. One example could be the utilisation of fossil-based carbon dioxide from power plants to produce algae or power-to-x-products which are then subsequently used in different forms and applications. With regards to the sustainability certification of these products, a number of new challenges and questions (e.g., system boundaries, sustainability criteria, allocation, etc.) for certification activities was brought up during the expert interviews (please see Table A10).

Due to the currently insignificant market relevance of these new products or feedstock, nearly no blueprints for sustainability assessments but also for sustainability certification do exist so far:

- for algae or bacteria production and for

- $\mathrm{CO}_{2}$ capture (e.g., from air or power plants) and (e.g., for PtX). 


\subsubsection{EOL in Existing Principles and System Boundaries}

The field of sustainability certification in the EU BBE has, in recent years, been driven largely by the developments in the bioenergy sector [52]. Certification in this sector aims mainly to address major issues and topics that are often highlighted in the debate about the general sustainability of bioenergy (e.g., environmental and social issues related to the production or the supply of the biomass used for energy production). Consequently, our analysis of the criteria and indicators currently used showed clear foci on criteria related to sustainable production of biomass as well as on the processing technologies used for the production of energy carriers, materials or other products from biomass. Contrarily, especially EOL scenarios for bio-based products are not adequately reflected so far. With a growing bio-based economy and increasing cascading use effects, this aspect could rapidly gain more importance in the future.

Generally, criteria aiming to address sustainability aspects related to different forms of after-use-phases criteria are only sporadically used so far. Examples which could be found are criteria such as: minimum recycled content in a product, implemented waste management, intended cascading use, etc. (see criteria database [24]). Input regarding this topic received during the expert interviews is described in Table A11.

\subsubsection{Traceability of Sustainability and Certificates along the Value Chain}

Finally, in addition to the previous points, which mostly address specific aspects related to sustainability criteria for certification, the aspect of traceability of sustainability characteristics (i.e., specific characteristics such as, for example a GHG emission information of products from the different processes of the value chain) and certificate information throughout the complete value chain of a bio-based product was mentioned by several of the experts interviewed (see Table A12).

The point of achieving a consistent, reliable and trustworthy traceability throughout the entire value chain would be an important step to reduce the potential for misuse of certificates, incorrect claims and to increase the overall integrity of sustainability certification. Consequently, pressing sustainability risks such as deforestation or misuse due to false claims (e.g., waste declarations, etc.) could be at least partly addressed by increasing the availability of consistent and complete chains of information.

For this purpose, future activities in the EU BBE should aim to establish instruments to transport sustainability characteristics through the supply chain, ideally independently from the issuing certification framework. This would support the development of meta-standards based on a mutual recognition of different certification frameworks. As a consequence, market actors could use different certification frameworks for different parts of the value chain (e.g., one framework certifying the biomass production process and another certifying the conversion process) under one meta-standard. Potentially database solutions on national (e.g., concepts such as the German NABISY database), or ideally on EU level could be one possible solution for this problem. However, this would require the existence of greater compatibility and established links between the various frameworks as well as general requirements leading to a (possibly mandatory) use of overarching database solutions. A prominent example on the member state level is the Nabisy database, which includes certificate information for all biofuels counted towards the national quota in Germany. The use of this database allows auditors to check and control specific claims made by market actors involved in the chain of custody. According to the currently available drafts for a recast of the RED after the 2021 timeframe, the EU commission recognises the importance of the registries and databases as tools to trace sustainability characteristics in a trustworthy manner. The current proposal for the new RED aims at the development of a European register for biomethane to decrease existing burdens related to international trade and recognition of sustainable biomethane. 
3.3. Gaps in Sustainability Standards for Bio-Based Products: General Issues and First Suggestions Derived by Experts Consultation

Our work with standardisation committees and standardisation experts at the European, international and national levels (see also Appendix D) led to valuable inputs, which can be organised into two categories:

- Suggestions related to improving the existing EN 16751 standard (Europe's most prominent sustainability assessment standard for bio-based products),

- $\quad$ Standardisation issues beyond the scope of EN 16751.

Determining which suggestions are related to the horizontal standard EN 16751 described below and which address additional topics was important in this regard. As an example, most of the suggestions we received regarding EN 16751 referred to issues for which a common, horizontal solution for all groups of bio-based products is unlikely. The responses also focussed on LCA, a topic covered by the standard EN 16760. LCA is also important for comparing bio-based products with fossil-derived ones, and this is currently also not covered by the narrow scope of EN 16751. Therefore, we also consider this topic separately.

\subsubsection{Suggestions Related to EN 16751}

The standard EN 16751 Bio-based products-Sustainability criteria was developed by CEN TC 411, whose main goal is to provide standards for horizontal aspects of bio-based products [53]. The IEC defines a horizontal standard as a standard on fundamental principles, concepts, terminology or technical characteristics, relevant to a number of technical committees (see IEC Guide 108). These standards also have the purpose of avoiding duplication of work and contradictory requirements [54]. According to ANSI, these general, basic standards are to distinguish from vertical, also called application standards.

As the focus of TC 411 is on horizontal standards, it has no intention to present threshold or default values. This is left to specific product standards or political decisions [53]. In this context, we also learned by our interviews that experts distinguish between the system-based approach of horizontal standards and the more performance-based approach in standard setting.

Experts at standardisation committees suggested to develop assessment methods and thresholds for the criteria of EN 16751. Threshold values can be used to check conclusively whether a specific indicator was fulfilled based on measurable and quantifiable parameters. Based on the product-independent focus of this horizontal standard, opportunities to define common evaluation methods and corresponding thresholds are limited. Nevertheless, there are potential exemptions. There are issues that are relevant for the assessment of bio-based products in general, and there are also requirements which can be specified easier than others.

Depending on the specific nature of a criterion and its respective indicator(s), there are areas in which fulfilment requires the definition of threshold values. In other areas, fulfilment can be proven with a simple yes/no condition. Requirements, which can be easily specified by such a simple condition, refer in particular to social and economic criteria, for example to the requirement "no child labour". Therefore, it is important to check the potential to define requirements on a horizontal level whenever possible. Furthermore, suggestions for common yes/no conditions regarding the use of grassland and forests are described at the end of this Section. These are especially relevant for the first life cycle stage of bio-based products.

During our information exchange with the experts interviewed, it was also communicated that economic sustainability is undervalued within EN 16751. In addition to this, our interview series with standardisation experts showed that the adoption of EN 16751 in product-specific standards is not as it should be. According to the understanding of an expert, only a bio-based solvent standard (drafted as EN 16766) and a surfactant equivalent (CEN/TS 17035) contain a requirement to use EN 16751 to show sustainability characteristics in Europe. More standards with a similar requirement would contribute 
to the promotion of sustainability criteria and stimulate their application. Closer collaboration with the TCs working on vertical standards for bio-based products is suggested.

\subsubsection{Standardisation Issues beyond the Scope of EN 16751}

This sub-section summarises eight additional suggestions for further standardisation work by standardisation committees and their representatives.

1. Provide assessment methods and thresholds for the criteria of EN 16751, if they cannot be defined via horizontal standardisation

As mentioned briefly before, the development of a certification scheme for sustainable bio-based products requires thresholds based on specified assessment methods. Experts interviewed emphasised that the specification of the assessment methods themselves had also not been carried out yet. Therefore, it is suggested to regard the work on assessment methods and thresholds as a high priority. Considering that the scope of EN 16751 excludes the establishment of "thresholds or limits", additional standards are needed. A specific issue in this regard is also the fact that EN 16751 will not be updated before 2021 due to CEN's review period of 5 years for EN standards. Separate standardisation work might also provide faster results in this regard. A standard providing general assessment methods may be created by the same CEN TC/411, while the TC's scope requires that the specification of thresholds is carried out by other TCs in any case.

2. Provide assessment methods and thresholds for ISO 13065 criteria: if necessary, by additional standards

Specifying assessment methods and thresholds, the sustainability standard ISO 13065, developed by ISO/PC 248, can provide various advantages. The results could also be used as examples and foundation for further standardisation efforts in the field of bio-based products. According to an expert, ISO/PC 248's output should be developed further regarding "criteria that can be evaluated quantitatively and qualitatively and specific levels of sustainability". Nevertheless, he described the challenge of creating levels of sustainability in such an overarching standard that they are suitable for all feedstocks and continents. It was impossible to agree on thresholds in this standard besides providing examples in its annex.

Two solutions are suggested in this regard. The first one refers to the development of very generic indicators which facilitate a basic level of international consistency.

In addition, appropriate coordination between horizontal and vertical standardisation activities is important. Suggesting and assuming the development of additional standards in this regard, an expert added that the creation of a more specific standard based on ISO 13065, e.g., "for a certain fuel from a specific feedstock in certain climatic conditions", could facilitate the determination of such threshold values. Such standards would provide the opportunity to add "a lot more detail and potentially even thresholds".

3. Facilitate a cradle to grave or cradle-to-cradle analysis of bio-based products

EN 16751 has a restricted scope that considers the life cycle stages ("feedstock" and "production" or "cradle" to "gate" only). Advantages of bio-based products further downstream are therefore not recognized. An example, an interviewee illustrates this as follows: "A biodegradable bio-based plastic has an EOL option that emits short cycle carbon only. A petrochemical plastic that is biodegradable contributes to net long cycle carbon emissions as it is decomposed. On the other hand, the energy needed to produce the petrochemical plastic may be much less than an equivalent bio-based plastic. Moreover, if non-renewable energy is used in the production of a bio-based product this may lead to greater (fossil) carbon emissions. This sort of impact (e.g., carbon balance that spans the entire lifecycle) is not currently supported". The interview series led us to suggest the creation of a basic 
cradle-to-grave standard, which also considers the EOL stage, or, if possible, even a cradle-to-cradle standard, which also considers circular issues of bio-based products. The circular aspect will be also discussed later in this section.

4. Provide a standard which facilitates comparisons of bio-based and fossil-derived products

As the previous section has partly shown, expert suggestions to specify assessment methods for EN 16751 were linked with comments on the relevance of comparisons with fossil-derived products regarding the three sustainability pillars and entire life cycle considerations. Currently, a comparison between both kinds of products based on EN 16751 is not possible. This standard explicitly excludes fossil content, although, for example, social and economic impacts could be compared relatively easily.

As an example of the advantages of a new standard in this context, an expert mentioned that bio-based solvents can have superior characteristics compared to fossil ones. Further research by the authors identified the solvent Cyrene as a good example for this. It can be directly derived from waste cellulose in two simple steps, therefore having a high stoichiometric biomass utilization efficiency. CyreneTM has demonstrated a similar solvent performance to toxic fossil-derived solvents, whose industrial synthesis involves multiple reaction steps (see [55]).

Several superior characteristics of bio-based products in general have even been highlighted by the European Commission: " ( . . ) higher process efficiency can be obtained (in the production of bio-based products), resulting in a decrease in energy and water consumption, and a reduction of toxic waste. As (bio-based products) are derived from renewable raw materials, (they) can help reduce $\mathrm{CO}_{2}$ and offer other advantages such as lower toxicity or novel product characteristics (e.g., biodegradable plastic materials)".

An additional specific example for superior characteristics is provided by smart drop-in chemicals. These chemicals are chemically identical to existing ones, but their bio-based pathways provide advantages. Carus et al. 2017 ([56]) uses the term 'smart drop-ins' if at least two of the following superiority criteria apply: the biomass utilization efficiency from feedstock to product is significantly higher compared to other drop-ins, and/or compared to all alternatives, their production requires significantly less energy and/or their time-to-product is shorter due to shorter and less complex production pathways and/or less toxic or harsh chemicals are used or they occur as by-products during their production process.

These examples show the superior characteristics of bio-based products clearly, both in general, and with respect to specific product groups. Therefore, a standard which facilitates demonstrations of these advantages would promote their market up-take or, as an interviewee formulated it, "promote the market and strengthen (the) trade (of bio-based products)". Nevertheless, experts describe that the comparison of upstream environmental impacts is not suitable, given the very different feedstocks. As a solution, we suggest discussions in CEN/TC 411, together with stakeholders of specific bio-based product groups (for example producers and public procurers) in this regard. If facilitating comparisons with fossil-based products by a horizontal standard appears to be difficult, information exchange on the level of product standardisation is important to create synergies where possible.

\section{Consider iLUC and related issues appropriately by standardisation}

There is international recognition that the production of bio-based products instead of fossil-based ones can reduce greenhouse gas emissions and contribute to the adaptation to climatic change. However, as bio-based materials are ultimately obtained from land or sea, additional effects require consideration. These effects can moderate environmental performances and the original purpose of sustainability. iLUC has been defined as an unintentional, negative, displacement effect of commodities in the primary sector such as agriculture causing additional land use changes [48].

Screenings and analysis of documents in the Perinorm database showed that iLUC represents a gap on the level of international standardisation. Likewise, experts, for example from the former ISO/PC 248, highlighted the need for action in this regard. The Dutch standard NTA 8080-1:2015 
considers low iLUC risk (see also Section 3.2.4). The requirements of this standard are also used for certification based on the standard NCS 8080:2017 and the Better Biomass certification scheme. Nevertheless, NTA 8080:1 describes specific limitations, for example, concerning new understandings and new issues such as "cascading ILUC" and "carbon debt" (see Appendix C). Based on the input of the interview series, we suggest initiating activities to specify iLUC-related requirements on a European level. As mentioned earlier, CENT/TC 383 plans to make changes to the EN 16214-series on sustainability criteria for biomass for energy use to include the revised standards references to the 2015 iLUC Directive modifying both the Fuel Quality Directive (FQD) and the RED. Therefore, this work could be a starting point for standardisation activities for bio-based products, including the determination of assessment measures and thresholds.

6. Develop standards that provide guidance on social and economic LCA

According to expert opinion (see Appendix C; Tables A1-A4), social LCA (S-LCA) would bring the assessment of social sustainability of bio-based products on a par with environmental sustainability. Considering economic LCA by standardisation was also suggested. In addition to this, an interview of the interview series in the technical committees emphasised the need for a better link between EN 16751 and LCA standards, referring to existing LCA standards and the relation to future ones as well.

\section{Create standards for the circular economy}

The European Commission is aware of the importance of the Circular Economy and has developed, for example, the Circular Economy Action Plan [57]. In line with expert suggestions (see Table A5), work on standards in this area has to be regarded as a priority. Appropriate standards should be focused on design aspects of products, promoting products that are designed to be easily refurbished, remanufactured, reused, recycled, biodegraded safely. Specifying the need for action, an interviewee of the general expert interview series referred to the need for standardised methods to measure circularity characteristics. The British standard BS 8001:2017 Framework for implementing the principles of the circular economy in organizations might be used as a starting point in this regard.

8. Standardise sustainability criteria for bio-based polymers and lubricants

Most suggestions of the experts in both parts of our analysis referred to standardisation issues of bio-based products in general, not to specific product groups. Bio-based polymers and lubricants, for which product-specific standards were suggested, were an exemption in this regard. The bio-based polymer turnover was about $€ 13$ billion worldwide in 2016. Nevertheless, they represent only a share of $2 \%$ of the global polymer market and a significant increase in their production capacity is forecasted [58]. Likewise, the market of bio-lubricants is growing significantly, from over 630 kilo tons in 2015 to expected 1115 kilo tons by 2024, growing at 6.9\% Compound Annual Growth Rate (CAGR) from 2016 to 2024 [59]. These quantities correspond a market size of $\$ 2.92$ ( $€ 2.47$ (Exchange rate from 30 November 2017)) billion by 2024. The specific need for action regarding the development of sustainability criteria for both kinds of products was recognised by experts. As mentioned earlier, not only do criteria have to be developed, but assessment methods and thresholds as well.

\subsection{Summary of Gaps Identified and Potential Links to Future Research Acticities}

The gaps identified and described in Sections 3.1 and 3.2 refer to different sustainability pillars. To summarise the findings and prepare subsequent assessment steps, they were clustered according to a differentiation between general, environmental, social and economic criteria as well as specific ones. This selection might help to structure and prioritise action items for further research work. This information is included in Table 4. Furthermore, it was specified whether the gaps refer to EOL or LCA topics and whether they also address regulatory issues. 
Table 4. Structuring the action items for the further work in the context of this report.

\begin{tabular}{|c|c|c|c|}
\hline Gap and Sustainability Pillar & EOL Topic & LCA Topic & $\begin{array}{c}\text { Topics for Work on } \\
\text { Regulatory } \\
\text { Requirements }\end{array}$ \\
\hline $\begin{array}{l}\text { General criteria } \\
\text { Bio-based content and recyclability/biodegradation }\end{array}$ & $\mathrm{x}$ & $\mathrm{x}$ & \\
\hline $\begin{array}{l}\text { Environmental criteria } \\
\text { GHG mitigation thresholds/GHG emission calculations } \\
\text { (indirect) land use change GHG emissions } \\
\mathrm{SO}_{2} \text { equivalents } \\
\mathrm{PM} 10 \\
\text { Guarantee of no deforestation after a certain cut-off date }\end{array}$ & & $\begin{array}{l}x \\
x \\
x \\
x\end{array}$ & $x$ \\
\hline $\begin{array}{l}\text { Economic criteria } \\
\text { Legality of sourcing } \\
\text { Land use efficiency } \\
\text { Secondary resource efficiency } \\
\text { Functionality (Output service quality) } \\
\text { Levelised life-cycle cost }\end{array}$ & $\mathrm{x}$ & $\begin{array}{l}x \\
x\end{array}$ & $x$ \\
\hline $\begin{array}{l}\text { Social criteria } \\
\text { Core labour standards } \\
\text { Risks for negative impacts on food prices and supply } \\
\text { Land use rights } \\
\text { Specific issues }\end{array}$ & & & $\begin{array}{l}x \\
x \\
x\end{array}$ \\
\hline $\begin{array}{l}\text { Algae or bacteria production } \\
\mathrm{CO}_{2} \text { capture } \\
\text { EOL scenarios (cascading, recycling, etc.). } \\
\text { EOL criteria, e.g., minimum recycled content in product, } \\
\text { implemented waste management, intended cascade use } \\
\text { Cross compatibility \& recognition between the } \\
\text { certification systems }\end{array}$ & $\begin{array}{l}\mathrm{x} \\
\mathrm{x} \\
\mathrm{x} \\
\mathrm{x}\end{array}$ & $\begin{array}{l}\mathrm{x} \\
\mathrm{x} \\
\mathrm{x}\end{array}$ & $x$ \\
\hline
\end{tabular}

\section{Discussion}

In recent years, different strategies, policies, certification frameworks, and standards to assess bio-based products have been developed in Europe and worldwide. In addition, the adoption of the European Bioeconomy Strategy in 2012, various additional actions have also shaped the path of the future BBE in Europe.

Nevertheless, need for action has remained, in particular regarding the sustainability assessment of bio-based products. This paper presented first results regarding existing gaps in sustainability certification and standardisation. In total, we analysed approx. 100 certification frameworks (45 in a detailed in-depth analysis), conducted interviews with 20 international experts, and analysed a wide range relevant standards and activities of standardisation committees in the BBE sectors. Information on the sustainability certification landscape and the different schemes was summarised in a database (see [24]), which is publicly available.

Interviews with experts form the starting point for the analyses of research demand regarding certification and standardisation activities. Several topics for future research demand were identified (e.g., to address specific products, such as, for example, bio-based polymers and lubricants) throughout this process.

This analysis revealed an impressive number of existing certification frameworks, criteria, indicators and applicable standards. In particular, experts from certification frameworks and certification bodies stressed the importance of improving the existing work instead of creating completely new criteria or even a completely new certification scheme. Quite contrarily, experts from science, representing a more holistic understanding of sustainability, addressed a number of specific gaps regarding principles, criteria or indicators currently not sufficiently addressed in sustainability certification and standardisation. The assessment of current sustainability certification 
revealed seven topics with a demand for future research and development (gaps and weaknesses in criteria and indicator sets, harmonisation in criteria assessment and operationalisation, legislation and consensus for minimum criteria in all BBE sectors, leakage effects from EU BBE policies, new innovative, inter-sectoral products, EOL, traceability of sustainability and certificates along the value chain).

In addition to the general standardisation needs identified during expert interviews with standard bodies, five specific gaps regarding general criteria, criteria for the three sustainability pillars, and several specific issues mentioned in Section 3 built the foundation for the analysis of standardisation options and various standardisation recommendations.

Furthermore, specific recommendations related to EN 16751 standardisation activities could be drawn. Of fundamental importance is that the standard is adopted for certification and that certification bodies adjust their schemes appropriately. By the time of our analysis, it was too early to observe changes in this regard. Based on the standard, specified indicators and assessment measures, usable for auditing processes have to be developed. In line with this, thresholds are needed. The work on indicators and assessment methods requires decisions, which solutions can be provided on the level of this horizontal standard and which issues must be addressed by specific product standards. Threshold issues outside the scope of EN 16751 and TC 411 make appropriate coordination with other TCs necessary.

Recommendations to address additional standardisation gaps of the sustainability assessment for the bio-based economy could also be drawn. Comparisons of bio-based and fossil-derived products should be facilitated, as well as analyses, which consider at least the LCA stages, cradle to grave. To provide LCA criteria, methods for social and economic LCA also need to be specified. In line with land use practice in the area of bio-energy, the protection of forests and grassland should be ensured. Regarding iLUC and carbon debt, appropriate measures have to be developed and considered by appropriate standardisation activities. Specifications for specific EOL issues are needed as well.

Based on the horizontal standard EN 16751, suitable product standards have to be created. Specified requirements and thresholds are needed in the relevant sub-areas of the bio-economy, while new product areas also have to be considered appropriately. Regarding specific bio-based products, standardised sustainability criteria and thresholds are needed, for example, for bio-based polymers and lubricants. Bio-gasification is an additional area requiring further exploration regarding standardisation needs. Finally, the standardisation needs of the emerging area circular economy demand specific considerations to make cradle-to-cradle analyses of bio-based products possible.

\section{Conclusions}

Future research activities in the context of sustainability assessment and certification for bio-based materials can build on a significant amount of existing certification frameworks, criteria sets, tools, and standardisation work. It is an important challenge to adapt and improve the existing building blocks from various sectors of the BBE to be used in a robust, reliable and trustworthy certification approach for the future BBE in the EU.

The currently existing criteria and indicators cover a wide range of sustainability aspects. However, we found that a number of principles and topics have not been adequately reflected so far. The respective criteria listed on the previous page refer to all sustainability pillars of bio-based products.

In addition to the question of additional indicators, criteria and standards, the actual operationalisation, application and implementation in certification practice seems to be carried out very differently between the existing frameworks. In practice, this can lead to differences in quality but also in price differences for the actual certification process. To address these points, support for the practical implementation of tools for sustainability assessment is necessary.

Interestingly, our interviews with experts have shown individual perspectives and expectations regarding the future development of certification and standardisation activities in the EU BBE. Generalising, interviewed experts from science and policy have tend to focus on aspects regarding the development of more holistic and comprehensive criteria and indicator sets (i.e., gaps regarding 
criteria and indicators) and the elimination of leakage effects (e.g., iLUC effects) from a missing level playing field regarding the sustainability requirements between the different BBE sectors. The latter has also been brought up by experts from industry, since this issue might also create market barriers and distortions hindering the development of meta-standards with mutual recognitions of different certification frameworks across the different BBE sectors. In addition, and quite contrarily to the statements received regarding gaps in criteria sets, experts from certification schemes and certification bodies did not see demand for additional criteria and indicators. Instead, they addressed demand for research regarding assessment tools and guidelines which would allow for a greater harmonisation of the actual implementation of sustainability criteria in certification practices.

Sustainability certification can be considered as one important tool to implement targets regarding a sustainable development from public or private sector and to increase and preserve the general societal acceptance of the BBE. In addition, sustainability assessment tools will allow providing evidence of the claimed better environmental superiority of bio-based products, as requested by policy makers. Currently, some of the major sustainability issues related to advanced sectors of the BBE (e.g., the bioenergy sector) can so far not be directly addressed with the existing sustainability certifications. For example, aspects such as indirect land use change, carbon debt, or food security risks can often not be measured directly. In fact, they have to be modelled [42]. To complement existing modelling activities for the quantification of iLUC risks associated with the development of a BBE, additional research is needed to develop robust criteria and indicators for an iLUC risk assessment during on-farm audits and certification. Secondly, the introduction of (mandatory) sustainability criteria (including criteria related to the protection of land with high carbon content and a high biodiversity value [11]) for all sectors of the BBE would help to create a level playing field and to reduce associated leakage effects.

In general, certification schemes are available for products which are close to market. On the other hand, new products (e.g., from algae) are not appropriately considered by the existing sustainability assessment frameworks.

Finally, bio-based value chains can be long and complex and involve a significant number of market participants, producers, suppliers, and users. For a growing economy, tools, which allow tracing information on sustainability characteristics and certificate parameters, need to be developed. Database solutions can help to solve this problem.

The potential research demand identified with this study covers a wide range of topics to be addressed by different stakeholder and scientific disciplines. The topics identified can be taken up by research consortiums and projects. A number of the topics addressed in this paper will be subject to the research activities of the EU H2020 project STAR-ProBio, which aims to develop tools for sustainability certification.

Author Contributions: Conceptualization: S.M., S.W., L.L. and D.T.; Data curation: D.M., B.S., S.W. and L.L.; Investigation: S.W., D.M., L.L. and S.M. Methodology S.M., D.M., S.W. and L.L.; Supervision, D.T.; Validation, S.W. and B.S.; Writing-original draft, S.M., S.W., D.M., L.L. and B.S.; Writing-review \& editing, D.T. and B.S.

Funding: This research was funded by the European Union's Horizon 2020 research and innovation programme under grant agreement No. 727740

Acknowledgments: The contents of the paper are a part of the findings of the project STAR-ProBio. STAR-ProBio has received funding from the European Union's Horizon 2020 research and innovation programme under grant agreement No. 727740. Re-use of information contained in this document for commercial and/or non-commercial purposes is authorised and free of charge, on the conditions of acknowledgement by the re-user of the source of the document, not distortion of the original meaning or message of the document and the non-liability of the STAR-ProBio consortium and/or partners for any consequence stemming from the re-use. The STAR-ProBio consortium does not accept responsibility for the consequences, errors or omissions herein enclosed. This document is subject to updates, revisions and extensions by the STAR-ProBio consortium. Questions and comments should be addressed to: http://www.star-probio.eu/contact-us/."

Conflicts of Interest: The authors declare no conflict of interest. 


\section{Appendix A - Information on Analysed Certification Frameworks}

Part of the gap assessment for this paper was based on a comprehensive review of existing sustainability certification frameworks. In a stepwise approach, we identified sustainability frameworks relevant for the BBE and selected half of the schemes identified to be analysed in an in-depth assessment. Because of the first step, a matrix including the currently available and relevant schemes for the sustainability certification in the EU BBE was produced. The matrix is presented on the following pages. One of the products of our detailed analysis of the currently available certification frameworks is a database, including all criteria and related indicators.

This database is available at: http:/ /www.star-probio.eu/wp-content/uploads/2017/12/StarProBio_certification_criteria.xlsx. 


\begin{tabular}{|c|c|c|c|c|c|c|c|c|c|c|c|}
\hline \multirow{2}{*}{\multicolumn{2}{|c|}{ Sector }} & \multirow{2}{*}{ Label } & \multirow{2}{*}{ Initiative } & \multirow{2}{*}{$\begin{array}{l}\text { Certifi- } \\
\text { cation } \\
\text { scheme }\end{array}$} & \multirow{2}{*}{ Name } & \multicolumn{3}{|c|}{ Scope } & \multicolumn{3}{|c|}{ Criteria } \\
\hline & & & & & & Geographic & Feedstock & Supply Chain & Social & Environment & Economic \\
\hline Bioenergy & $\begin{array}{l}\text { Liquid } \\
\text { biofuels }\end{array}$ & $\begin{array}{l}x \\
x \\
x \\
x \\
x \\
x\end{array}$ & & $\begin{array}{l}x \\
x \\
x \\
x \\
x \\
x\end{array}$ & $\begin{array}{l}\text { International Sustainability \& } \\
\text { Carbon Certification (ISCC) } \\
\text { REDcert EU } \\
\text { Bonsucro EU } \\
\text { Roundtable on Sustainable } \\
\text { Biomaterials EU RED (RSB EU } \\
\text { RED) } \\
\text { Biomass Biofuels voluntary } \\
\text { scheme (2BSvs) } \\
\text { Red Tractor Farm Assurance } \\
\text { Combinable Crops \& Sugar } \\
\text { Beet (Red Tractor) } \\
\text { Scottish Quality Farm } \\
\text { Assured Combineable Crops } \\
\text { Limited (SQC) } \\
\text { Roundtable on Sustainable } \\
\text { Palm Oil RED (RSPO) } \\
\text { Better Biomass NTA } 8080 \\
\text { HVO Renewable Diesel } \\
\text { Scheme for Verification of } \\
\text { Compliance with the RED } \\
\text { sustainability criteria for } \\
\text { biofuels } \\
\text { Gafta Trade Assurance } \\
\text { Scheme } \\
\text { KZR INiG System } \\
\text { Trade Assurance Scheme for } \\
\text { Combinable Crops } \\
\text { Universal Feed Assurance } \\
\text { Scheme } \\
\text { Certification System } \\
\text { adressing Indirect Impacts of } \\
\text { Biofuel (CIIB) }\end{array}$ & $\begin{array}{l}\text { global } \\
\text { Europe } \\
\text { (+Ukraine,B } \\
\text { elarus) } \\
\text { global } \\
\text { global } \\
\text { global } \\
\text { UK } \\
\text { north GP } \\
\text { global } \\
\text { global } \\
\text { global }\end{array}$ & $\begin{array}{l}\text { multiple } \\
\text { multiple } \\
\text { Sugar cane } \\
\text { multiple } \\
\text { multiple } \\
\text { cereals, } \\
\text { oilseeds, } \\
\text { sugar beet } \\
\text { cereals, } \\
\text { oilseeds } \\
\text { multiple } \\
\text { multiple } \\
\text { multiple } \\
\text { multiple } \\
\text { multiple } \\
\text { multiple } \\
\text { multiple } \\
\text { multiple }\end{array}$ & \begin{tabular}{|l|} 
full \\
full \\
full \\
full \\
full \\
until first \\
feedstock \\
delivery \\
point \\
until first \\
feedstock \\
delivery \\
point \\
full \\
full \\
full \\
\\
farm gate to \\
first \\
processor \\
full \\
farm gate to \\
first \\
processor \\
farm gate to \\
first \\
processor \\
farm gate to \\
first \\
processor
\end{tabular} & $\begin{array}{l}x \\
x\end{array}$ & $\begin{array}{l}x \\
x \\
x \\
x \\
x \\
x \\
x \\
x \\
x\end{array}$ & $\mathrm{x}$ \\
\hline
\end{tabular}

Figure A1. Cont. 


\begin{tabular}{|c|c|c|c|c|c|c|c|c|c|c|}
\hline & $x$ & & $\mathrm{x}$ & $\begin{array}{l}\text { ECOFYS - Methodologies for } \\
\text { the identification and } \\
\text { certification of Low ILUC risk } \\
\text { Biofuels } \\
\text { Austrian Agricultural } \\
\text { Certification Scheme (AACS) }\end{array}$ & EU+ & multiple & \begin{tabular}{|l|} 
farm gate to \\
first \\
processor \\
cultivation to \\
production
\end{tabular} & $x$ & $x$ & \\
\hline \begin{tabular}{|l|} 
Solid \\
biofuels
\end{tabular} & $x$ & & $x$ & $\begin{array}{l}\text { Sustainable Biomass } \\
\text { Partnership (SBP) } \\
\text { Green Gold Label (GCL) S1 } \\
\text { DINplus Short rotation } \\
\text { coppice sustainably grown } \\
\text { according to DIN EN 16214-3 } \\
\text { Nordic Ecolabeling (SWAN) } \\
\text { ISCC PLUS }\end{array}$ & $\begin{array}{l}\text { global } \\
\text { global } \\
\text { global } \\
\text { Denmark, } \\
\text { Finland, } \\
\text { Iceland, } \\
\text { Norway, } \\
\text { Sweden } \\
\text { global }\end{array}$ & $\begin{array}{l}\text { woody } \\
\text { biomass } \\
\text { woody } \\
\text { biomass } \\
\text { SRC wood } \\
\text { woody } \\
\text { biomass } \\
\text { multiple }\end{array}$ & \begin{tabular}{|l} 
from \\
cultivation to \\
energy \\
production \\
full \\
cultivation
\end{tabular} & $x$ & $\mathrm{x}$ & $\mathrm{x}$ \\
\hline Biogas & & $x$ & $x$ & $\begin{array}{l}\text { CIB- Biogasdoneright } \\
\text { Green Gas Certification } \\
\text { Scheme (GGCS) }\end{array}$ & Italy & $\begin{array}{l}\text { multiple } \\
\text { multiple }\end{array}$ & \begin{tabular}{|l|} 
production \\
process, \\
product \\
production to \\
use \\
\end{tabular} & & $x$ & $\mathrm{x}$ \\
\hline $\begin{array}{l}\text { Heat/ } \\
\text { Power }\end{array}$ & $x$ & $x$ & $x$ & 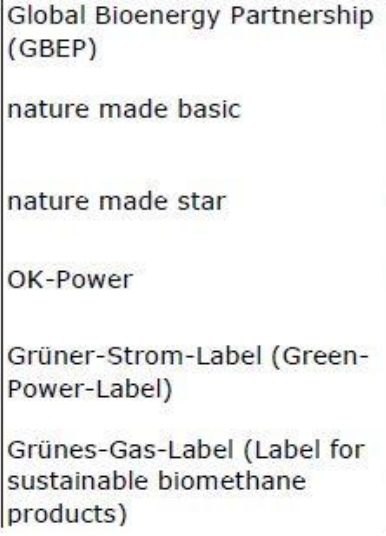 & $\underbrace{\text { global }}_{\text {Germany }}$ & $\begin{array}{l}\text { multiple } \\
\text { multiple } \\
\text { multiple } \\
\text { multiple } \\
\text { multiple } \\
\text { multiple }\end{array}$ & $\begin{array}{l}\text { full } \\
\text { energy } \\
\text { production } \\
\text { and delivery } \\
\text { energy } \\
\text { production } \\
\text { and delivery } \\
\text { power } \\
\text { production } \\
\text { power } \\
\text { production to } \\
\text { distri-bution } \\
\text { cultivation to } \\
\text { distri-bution }\end{array}$ & $x$ & $x$ & $\mathrm{x}$ \\
\hline
\end{tabular}

Figure A1. Cont. 


\begin{tabular}{|c|c|c|c|c|c|c|c|c|c|c|}
\hline & $x$ & $\begin{array}{l}x \\
x\end{array}$ & $x$ & $\begin{array}{l}\text { Laborelec certification system } \\
\text { (LBE) } \\
\text { Austrian Ecolabel } \\
\text { Council on Sustainable } \\
\text { Biomass Production (CSBP) } \\
\\
\text { Green-e } \\
\text { The global bioenergy } \\
\text { partnership sustainability } \\
\text { indicators for bioenergy } \\
\text { Testing framework for } \\
\text { sustainable biomass } \\
\text { Responsible Biomass } \\
\text { Certification scheme (RBC } \\
\text { scheme) }\end{array}$ & $\begin{array}{l}\text { Belgium } \\
\text { Austria } \\
\text { USA } \\
\text { global } \\
\text { global } \\
\text { global } \\
\text { global }\end{array}$ & $\begin{array}{l}\begin{array}{l}\text { woody } \\
\text { biomass, } \\
\text { agricultural } \\
\text { products } \\
\text { multiple }\end{array} \\
\text { multiple } \\
\text { multiple } \\
\text { multiple } \\
\text { multiple } \\
\text { multiple }\end{array}$ & \begin{tabular}{|l|} 
Biomass \\
production to \\
trans- \\
portation \\
power \\
production \\
production \\
and \\
conversion \\
of biomass \\
to bioenergy \\
full \\
full \\
full \\
production \\
and trade of \\
biomass
\end{tabular} & $x$ & $\begin{array}{l}\mathrm{x} \\
\mathrm{x} \\
\mathrm{x} \\
\mathrm{x}\end{array}$ & $\mathrm{x}$ \\
\hline Forestry & $\mathrm{x}$ & $x$ & $x$ & $\begin{array}{l}\text { Forest Stewardship Council } \\
\text { (FSC) CoC } \\
\text { Programme for the } \\
\text { Endorsement of Forest } \\
\text { Certification (PEFC) CoC } \\
\text { Eco- } \\
\text { Certified Composite (ECC) } \\
\text { Sustainability Standard } \\
\text { Sustainable Forestry } \\
\text { Initiative (SFI) }\end{array}$ & $\begin{array}{l}\text { global } \\
\text { global } \\
\text { USA } \\
\text { USA, Canada }\end{array}$ & $\begin{array}{l}\begin{array}{l}\text { woody } \\
\text { biomass } \\
\text { woody } \\
\text { biomass }\end{array} \\
\text { wood fiber } \\
\text { forestland }\end{array}$ & $\begin{array}{l}\text { full } \\
\text { full } \\
\text { full } \\
\text { cultivation }\end{array}$ & $x$ & $\begin{array}{l}\mathrm{x} \\
\mathrm{x} \\
\mathrm{x} \\
\mathrm{x}\end{array}$ & $\mathrm{x}$ \\
\hline $\begin{array}{l}\text { Con- } \\
\text { struction }\end{array}$ & $\mathrm{x}$ & & $x$ & $\begin{array}{l}\text { DGNB System } \\
\text { Green Building Rating } \\
\text { System BREEAM } \\
\text { Assessment System for } \\
\text { Sustainable Building (BNB) } \\
\text { Minergie }\end{array}$ & $\begin{array}{l}\text { Germany } \\
\text { Switzerland, } \\
\text { Lichtenstein }\end{array}$ & & $\begin{array}{l}\text { from cradle } \\
\text { to grave } \\
\text { design and } \\
\text { procure- } \\
\text { ment stage, } \\
\text { post con- } \\
\text { struction } \\
\text { stage } \\
\text { (optional) } \\
\text { from cradle } \\
\text { to grave }\end{array}$ & $\mathrm{x}$ & $\begin{array}{l}x \\
x\end{array}$ & $\mathrm{x}$ \\
\hline
\end{tabular}

Figure A1. Cont. 


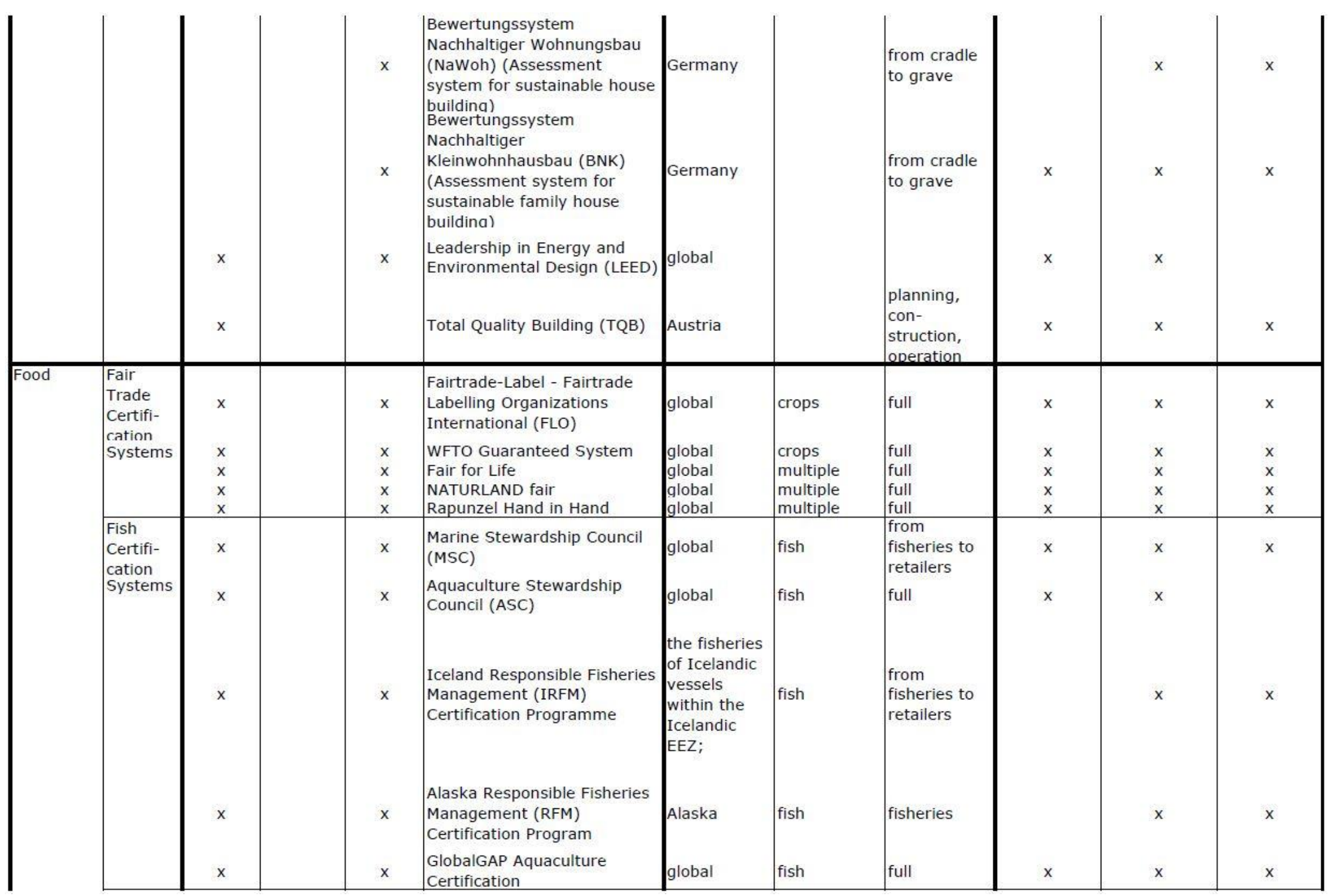

Figure A1. Cont. 


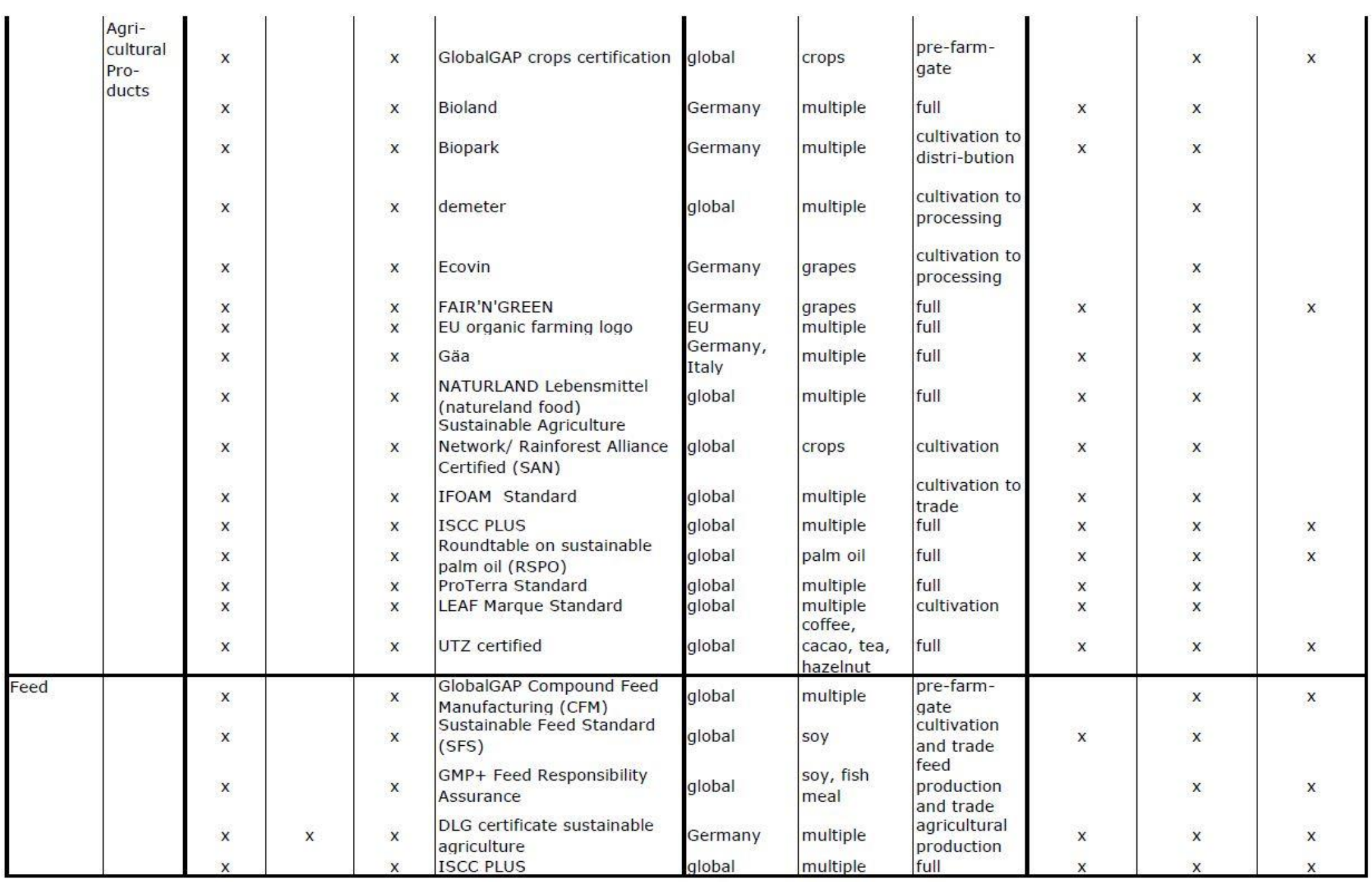

Figure A1. Cont. 


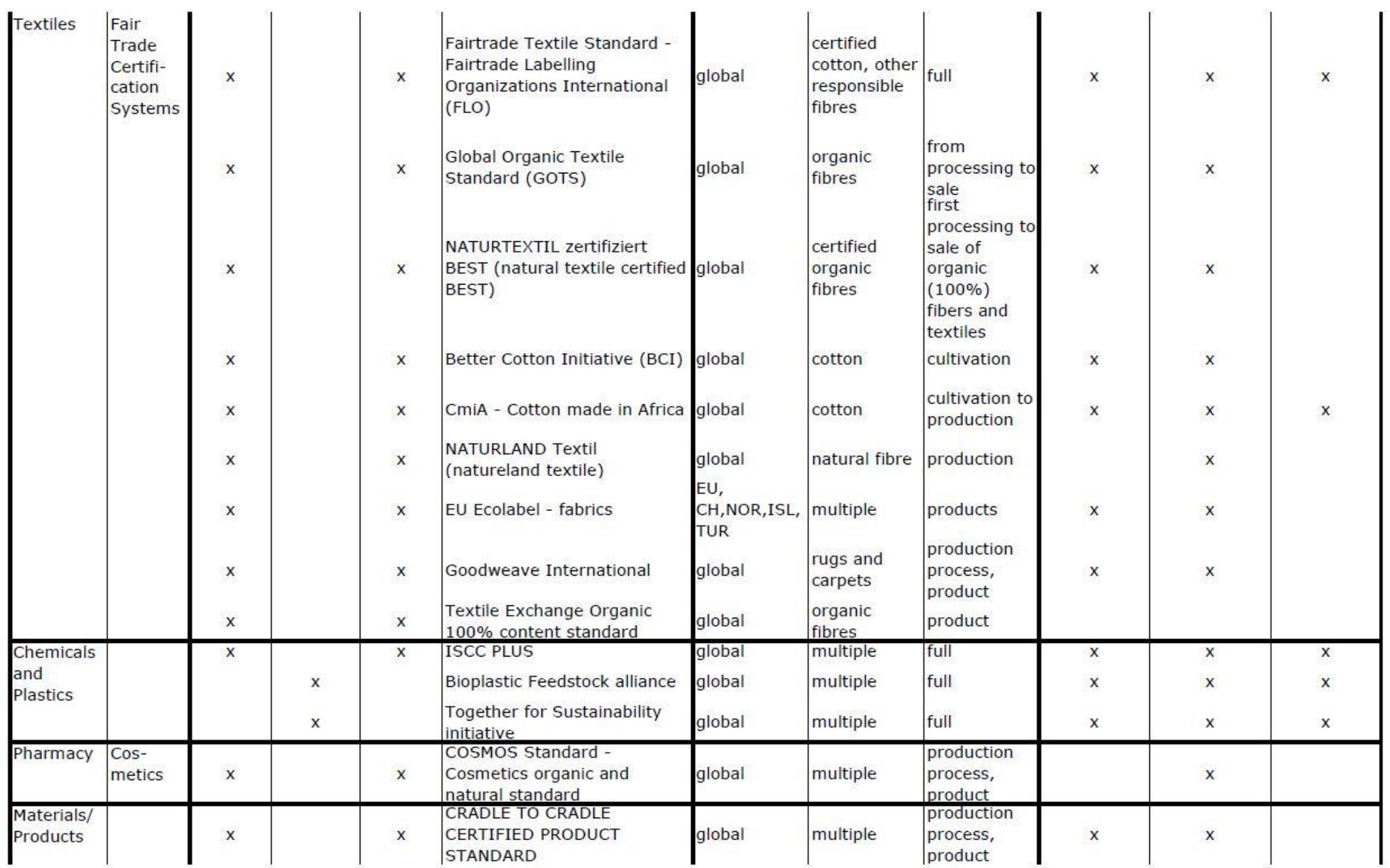

Figure A1. Cont. 


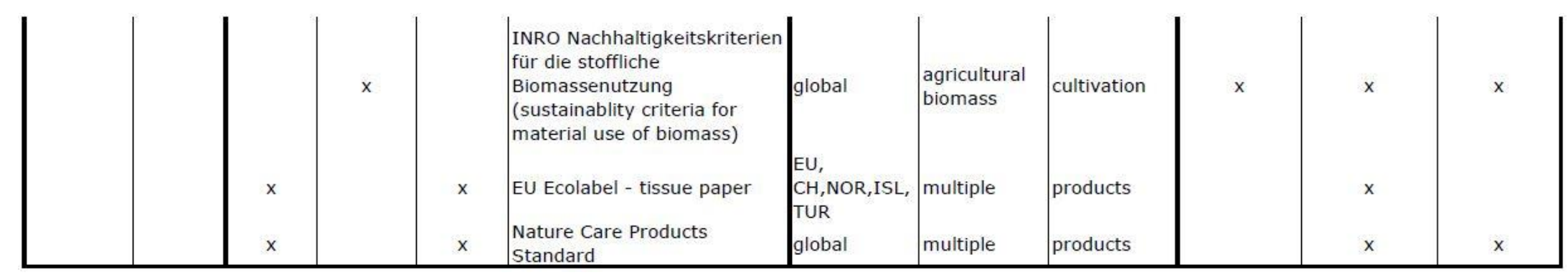

Figure A1. Overview on certification frameworks in the EU BBE. 
Appendix B —-Interview Guide/Questionnaire

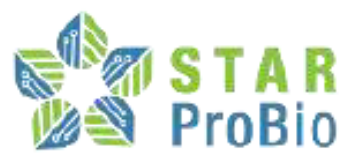

\title{
Interview guide on gaps in current sustainability assessment schemes
}

\author{
Introduction
}

STAR-ProBio is a three-year project (May 2017 - April 2020) and supports the European Commission in the full implementation of European policy initiatives, including the Lead Market Initiative in bio-based products, the industrial policy and the European Bio-economy Strategy. STAR-ProBio does so by developing sustainability assessment tools for bio-based products, and by developing credible cases for biobased products with the highest actual market penetration and highest potential for the future markets. STAR-ProBio integrates scientific and engineering approaches with social sciences and humanities-based approaches to formulate guidelines for a common framework promoting the development of regulations and standards supporting the adoption of business innovation models in the bio-based products sector. The aim of STAR-ProBio is to fill gaps in the existing framework for sustainability assessment of bio-based products, and improve consumer acceptance for biobased products by identifying critical sustainability issues in their value chains. This interview is part of the first work package "Screening and analysis of existing sustainability schemes for the bio-economy".

\section{Questions}

\section{Your background}

Please specify your background and stakeholder group in the bio-based economy and the key product- or process-related areas of your knowledge and activity briefly:

1.1 Product- or process-related background in the bio-based economy?

1.2 Stakeholder group?

$\square$ Producer, retailer etc.

$\square$ Consumer

$\square$ Certification and standardization bodies

$\square$ Public procurement

$\square$ Scientist

$\square$ Other, please specify

1.3 Country?

2. Barriers regarding the acceptance and demand for bio-based products

To what extent does (dis)trust of bio-based products affect their acceptance and demand on the market? 


\section{Gaps in sustainability assessment}

3.1 From your point of view, is there a need for new or additional criteria in sustainability assessment schemes to raise consumer trust in bio-based products, for example regarding product-related, environmental, social or economic aspects?
$\square$ Yes
$\square$ No

If yes: Please continue with the remaining questions of block 3 and block 4 . If no, please continue with block 5 .

3.2 In which topic area is there a need for new or additional criteria?
$\square$ product-related
$\square$ environmental issues
$\square$ economic issues
$\square$ social issues
$\square$ other, please specify

3.3 Please explain the kinds of assessment criteria that are needed in each topic area you selected in 3.2 .

\begin{tabular}{|l|l|}
\hline Topic area of 3.2 & Additional assessment criteria that are needed \\
\hline & \\
\hline
\end{tabular}

3.4 Optional: Please explain your considerations using one or more products as examples.

3.5 How should compliance with the criteria you proposed be measured? What methods should it be based on?

Criterion:

\section{Method:}

(please continue with additional criteria, if relevant)

3.6 Are there areas where the methodology for measuring specific issues in the sustainability assessment of bio-based products needs to be expanded, improved, or adapted?

$\square$ Yes

If yes: Please specify what is needed. 


\section{Standards to overcome current assessment gaps}

4.1 Do you think that current standards from CEN or ISO or national standards provide content that can be integrated into current sustainability assessment schemes to address the missing assessment criteria you described above?

$\square$ Yes $\rightarrow$ please continue with $4.2 \quad \square$ No $\rightarrow$ please continue with 4.3

$\square$ Depends on the criteria that are needed

$\rightarrow$ specific answers are possible below, you can refer to selected criteria by answering question 4.2 and to other criteria by answering question 4.3 .

4.3 Do you think that need for additional criteria could be addressed by:

a) extending current European standards and legislation?

$\square$ Yes

$\square$ No

If yes: Please specify the area(s) and your answer:

Need for additional criteria:

Name of the standard(s) and legislation to be expanded to address(es) the need:

Explanation on how this need can be addressed by standard and legislation extension:

b) new European standards and legislation?

$\square$ Yes

$\square$ No

If yes: Please specify the area(s) and your answer:

Need for additional criteria:

Explanation (potential content of new European standards to address this need):

c) If the answer on a) and b) is "no", what other solution(s) would you suggest? 
5. Good practice schemes

5.1 Are you aware of good practice schemes regarding sustainability assessment?

$\square$ Yes

$\square$ No

5.2 If yes: Please specify these schemes and describe their specific benefits.

5.3 Do you think new assessment criteria could enhance these schemes?
$\square$ Yes
$\square$ No

5.4 If yes: Please explain your thoughts.

\section{Policy gaps}

6.1 Is there a need for policy documents regarding sustainability assessment in new or emerging areas in the bioeconomy?
$\square$ Yes
$\square$ No

6.2 If yes: Please specify what is needed.

a) on the national level in Member States

b) on a European level

7. Additional comments

7.1 Do you have additional comments or suggestions for our project?

$$
\square \text { Yes } \square \text { No }
$$

7.2 If yes: Please share your thoughts.

Thank you very much for your time! 


\section{Appendix C-Identified Gaps and Corresponding Expert Interview Results}

Table A1. Selected summary of questionnaire answers with gaps in sustainability standards for bio-based products at standardisation issues beyond the scope of EN 16751 with emphasis on assessment methods and thresholds for criteria of EN 16751, if they cannot be defined via horizontal standardisation.

\begin{tabular}{ll}
\hline \multicolumn{1}{c}{ Identified Gap } & \multicolumn{1}{c}{ Expert Interview Answer } \\
\hline & $\begin{array}{l}\text { "Need for sustainability requirements (especially caps and } \\
\text { thresholds) for the bio-based economy as a whole (instead of } \\
\text { biofuels (bioenergy) only" }\end{array}$ \\
\cline { 2 - 2 } $\begin{array}{l}\text { Assessment methods and thresholds for } \\
\text { "Aditeria of EN 16751, if they cannot be } \\
\text { defined via horizontal standardisational requirements and criteria should not be associated } \\
\text { with economic burdens for operators." }\end{array}$ & $\begin{array}{l}\text { "The standard EN 16571 will be revised after 5 years } \\
\text { automatically The committee will meet again after 4-5 years } \\
\text { and decide whether there is a need for revision" }\end{array}$ \\
\cline { 2 - 2 } & "Minimum requirement for sustainable procurement ("EU \\
& $\begin{array}{l}\text { Bio-based"), for specific products (plastics ... ) also minimum } \\
\text { bio-based content ("quota") to be raised over time" }\end{array}$ \\
\hline
\end{tabular}

Table A2. Selected summary of questionnaire answers with gaps in sustainability standards for bio-based products at standardisation issues beyond the scope of EN 16751 with emphasis on assessment methods and thresholds for ISO 13065 criteria; if necessary, by additional standards.

\section{Identified Gap}

Expert Interview Answer

"ISO may be the best platform to define overarching requirements and guidelines for the definition of specific criteria. ISO 13065 gives an excellent start for bioenergy which should be mainstreamed for other bio-based products."

"EN 16751:2016 might need an update taking ISO 13065 into account"

“Need for new EU Standard similar to the RED with a regulatory framework for all supply chains dealing with biomass to ensure no-deforestation in products entering the European market, also for food, feed and chemicals

- $\quad$ more obligatory criteria for products containing biomass especially from outside the EU regarding protection of forests, grassland and consideration of indigenous people and their rights and legality

Assessment methods and thresholds for ISO 13065 criteria; if necessary, by additional standards
- $\quad$ EU may determine best practice certification/ assessment schemes and make specific forms and contents obligatory in such schemes

- $\quad$ EU to monitor existing schemes"

“RSB, ISCC, FSC ${ }^{\circledR}$ (if wood-based), may be considered to be frontrunner schemes, but they also should benchmark themselves against ISO 13065"

"Standardization of requirements for sustainable biomass and harmonization of certification/certification systems of sustainable biomass (ISO-Standard). The approach of mandatory sustainability criteria for biofuels in EU could be extended to other bio based products/markets. e.g., packaging, food, feed."

"Increase awareness about the properties of bio-based products utilising current European standards and labelling systems help to specify and communicate the properties of bio-based products in a clear and unambiguous way, thereby contributing to a level of certainty in the market. There will continue to be an ongoing need for new standardisation and labelling (single, unifying, identifiable) to create market certainty for the bio-based sector." 
Table A3. Selected summary of questionnaire answers with gaps in sustainability standards for bio-based products at standardisation issues beyond the scope of EN 16751 with emphasis on cradle-to-grave or cradle-to-cradle analyses of bio-based products.

\begin{tabular}{cc}
\hline Identified Gap & Expert Interview Answer \\
\hline $\begin{array}{c}\text { Cradle-to-grave or cradle-to-cradle } \\
\text { analyses of bio-based products }\end{array}$ & $\begin{array}{c}\text { "Better traceability along entire supply chain" } \\
\text { "Demand for more and standardised LCA assessment of } \\
\text { greenhouse gas emissions" }\end{array}$ \\
\hline
\end{tabular}

Table A4. Selected summary of questionnaire answers with gaps in sustainability standards for bio-based products at standardisation issues beyond the scope of EN 16751 with emphasis on standardisation of iLUC and related issues.

\begin{tabular}{cl}
\hline Identified Gap & \multicolumn{1}{c}{ Expert Interview Answer } \\
\hline \multirow{2}{*}{$\begin{array}{c}\text { Standardisation of iLUC and } \\
\text { related issues }\end{array}$} & $\begin{array}{l}\text { Clear demand for "criteria addressing the leakage effects from policies } \\
\text { and regulations for the European market to other parts of the world } \rightarrow \\
\text { iLUC and carbon debt" }\end{array}$ \\
\cline { 2 - 2 } & $\begin{array}{l}\text { Clear demand for "criteria to address risks and leakage effects regarding } \\
\text { to land use change, food security, etc." }\end{array}$ \\
\hline
\end{tabular}

Table A5. Selected summary of questionnaire answers with gaps in sustainability standards for bio-based products at standardisation issues beyond the scope of EN 16751 with emphasis on standards for the circular economy.

\begin{tabular}{cl}
\hline Identified Gap & \multicolumn{1}{c}{ Expert Interview Answer } \\
\hline \multirow{3}{*}{ Standards for the circular economy } & $\begin{array}{l}\text { "Consumers need more clarity on "bio-based" and "biodegradation"; } \\
\text { more clarity on how to recycle bio-based products" }\end{array}$ \\
\cline { 2 - 2 } & Demand for "standardised methods to measure circular issues" \\
\hline
\end{tabular}

Table A6. Selected summary of questionnaire answers with gaps in current sustainability certification activities with emphasis on gaps \& weaknesses in criteria \& indicator sets.

\begin{tabular}{|c|c|}
\hline Identified Gap & Expert Interview Answer \\
\hline \multirow{4}{*}{$\begin{array}{l}\text { Gaps \& weaknesses in } \\
\text { criteria \& indicator sets }\end{array}$} & Build on results from previous projects such as S2Biom \\
\hline & $\begin{array}{l}\text { "No need/demand for new criteria. However, on the level of indicators, } \\
\text { additional work is necessary" }\end{array}$ \\
\hline & $\begin{array}{l}\text { Demand for criteria related to "resource efficiency, bio-based content and } \\
\text { recyclability/biodegradation" }\end{array}$ \\
\hline & $\begin{array}{l}\text { Demand for criteria related to "bio-based content of products; bio-based label } \\
\text { such as USDA bio-preferred" }\end{array}$ \\
\hline
\end{tabular}


Table A7. Selected summary of questionnaire answers with gaps in current sustainability certification activities with emphasis on harmonisation in criteria assessment and operationalisation.

\begin{tabular}{cl}
\hline \multicolumn{1}{c}{ Identified Gap } & \multicolumn{1}{c}{ Expert Interview Answer } \\
\hline \multirow{3}{*}{$\begin{array}{c}\text { Harmonisation in criteria } \\
\text { assessment and operationalisation }\end{array}$} & $\begin{array}{l}\text { Harmonisation is needed for criteria such as: "guarantee of no } \\
\text { deforestation after a certain cut-off date, core labour standards, legality } \\
\text { of sourcing, land use rights, GHG emissions" }\end{array}$ \\
\cline { 2 - 2 } & $\begin{array}{l}\text { Main barrier for more harmonisation is "the lack of a level playing field" } \\
\text { "Existing criteria should be communicated better and be defined more } \\
\text { precisely" }\end{array}$ \\
\cline { 2 - 2 } & "Criteria are widely available. It is more a question of the actual \\
implementation and acceptance" & $\begin{array}{l}\text { "There seems to be no need for new criteria. More important to make } \\
\text { better use of existing criteria and tools" }\end{array}$ \\
\cline { 2 - 2 } & $\begin{array}{l}\text { Demand for "Better coverage of core social issues during audit. Better } \\
\text { risk analysis" }\end{array}$ \\
\hline
\end{tabular}

Table A8. Selected summary of questionnaire answers with gaps in current sustainability certification activities with emphasis on legislation \& consensus for minimum criteria in all BBE sectors.

\begin{tabular}{|c|c|}
\hline Identified Gap & Expert Interview Answer \\
\hline \multirow{12}{*}{$\begin{array}{l}\text { Legislation \& consensus for minimum criteria } \\
\text { in all BBE sectors }\end{array}$} & $\begin{array}{l}\text { "It is less important to introduce "additional" criteria, } \\
\text { it seems more important to mainstream sustainability } \\
\text { requirements to all kind of biomass production. We then } \\
\text { might need equivalent sets for production from }\end{array}$ \\
\hline & - $\quad$ agriculture \\
\hline & forestry \\
\hline & waste management \\
\hline & $\begin{array}{l}\text { - creation in laboratories and all kinds of } \\
\text { technical reactors" }\end{array}$ \\
\hline & $\begin{array}{l}\text { "In contrast to schemes for bio-energy and bio-fuels, } \\
\text { which are acknowledged by the Bio-energy Directive, } \\
\text { schemes for bio-based products are entirely voluntary. There } \\
\text { is no legal requirement to prove that bio-based products are } \\
\text { sustainable" }\end{array}$ \\
\hline & $\begin{array}{l}\text { "Sustainability requirements (especially caps and thresholds) } \\
\text { should be introduced for the bio-based economy as a whole } \\
\text { (instead of biofuels (bioenergy) only)" }\end{array}$ \\
\hline & $\begin{array}{l}\text { "New EU Standard similar to the RED with a regulatory } \\
\text { framework for all supply chains dealing with biomass to } \\
\text { ensure no-deforestation in products entering the European } \\
\text { market, also for food, feed and chemicals }\end{array}$ \\
\hline & $\begin{array}{l}\text { - } \text { more obligatory criteria for products containing } \\
\text { biomass especially from outside the EU regarding } \\
\text { protection of forests, grassland and consideration of } \\
\text { indigenous people and their rights and legality }\end{array}$ \\
\hline & $\begin{array}{l}\text { - EU may determine best practice } \\
\text { certification/assessment schemes and make specific } \\
\text { forms and contents obligatory in such schemes }\end{array}$ \\
\hline & - $\quad$ EU to monitor existing schemes" \\
\hline & $\begin{array}{l}\text { "We need sustainability criteria for ALL types of biomass } \\
\text { cultivation and also for food and feed. Equal changes and } \\
\text { equal burdens for all of them." }\end{array}$ \\
\hline
\end{tabular}


Table A8. Cont.

\begin{tabular}{|c|c|}
\hline Identified Gap & Expert Interview Answer \\
\hline & $\begin{array}{l}\text { "Generally, all schemes can be enhanced through new } \\
\text { criteria that are reasonable to increase sustainable products }\end{array}$ \\
\hline & $\begin{array}{l}\text { - obligatory criteria could help to set a baseline for all } \\
\text { assessment schemes requirements }\end{array}$ \\
\hline & $\begin{array}{l}\text { - new described EU regulations support the certification } \\
\text { process of the whole supply chain and its actors }\end{array}$ \\
\hline & $\begin{array}{l}\text { new described EU regulations also give incentives to } \\
\text { countries and producers outside the EU to change their } \\
\text { habits to still be able to sell their bio-based products }\end{array}$ \\
\hline & $\begin{array}{l}\text { - integrity and credibility of schemes must be improved } \\
\text { and monitored" }\end{array}$ \\
\hline & $\begin{array}{l}\text { Need for "Standardization of requirements for sustainable } \\
\text { biomass and harmonization of certification/certification } \\
\text { systems of sustainable biomass (ISO-Standard). } \\
\text { The approach of mandatory sustainability criteria for } \\
\text { biofuels in EU could be extended to other bio based } \\
\text { products/markets. e.g., packaging, food, feed." }\end{array}$ \\
\hline & $\begin{array}{l}\text { "Develop minimum consensus for a sustainability criteria set } \\
\text { for the bioeconomy" }\end{array}$ \\
\hline
\end{tabular}

Table A9. Selected summary of questionnaire answers with gaps in current sustainability certification activities with emphasis on leakage effects from EU BBE policies.

\begin{tabular}{ll}
\hline \multicolumn{1}{c}{ Identified Gap } & \multicolumn{1}{c}{ Expert Interview Answer } \\
\hline & $\begin{array}{l}\text { Demand for "criteria addressing the leakage effects from policies and } \\
\text { regulations for the European market to other parts of the world } \rightarrow \text { iLUC } \\
\text { and carbon debt" }\end{array}$ \\
\cline { 2 - 2 } $\begin{array}{l}\text { Leakage effects from EU BBE } \\
\text { policies }\end{array}$ & $\begin{array}{l}\text { Demand for "bottom up approaches for product certification based on } \\
\text { risk based criteria" }\end{array}$ \\
\cline { 2 - 2 } & "Leakage effects have to be addressed by both policies and certification" \\
\hline
\end{tabular}

Table A10. Selected summary of questionnaire answers with gaps in current sustainability certification activities with emphasis on new innovative, inter-sectoral products.

\begin{tabular}{cl}
\hline Identified Gap & \multicolumn{1}{c}{ Expert Interview Answer } \\
\hline \multirow{2}{*}{$\begin{array}{c}\text { New innovative, inter-sectoral } \\
\text { products }\end{array}$} & $\begin{array}{c}\text { "For algae or bacteria production there are nearly no blueprints for } \\
\text { sustainability assessments" }\end{array}$ \\
\cline { 2 - 2 } & No blueprints and frameworks for " $\mathrm{CO}_{2}$ from air by PtX" \\
\hline
\end{tabular}

Table A11. Selected summary of questionnaire answers with gaps in current sustainability certification activities with emphasis on End-of-Life (EOL).

\begin{tabular}{ll}
\hline Identified Gap & \multicolumn{1}{c}{ Expert Interview Answer } \\
\hline & $\begin{array}{l}\text { "Consumers need more clarity on "bio-based" and "biodegradation"; more clarity } \\
\text { on how to recycle bio-based products" }\end{array}$ \\
\cline { 2 - 2 } End-of-Life (EOL) & $\begin{array}{l}\text { "Capture downstream assessment characteristics (manufacture and so on) right up } \\
\text { to the end of life options" }\end{array}$ \\
\cline { 2 - 2 } & "Policy considerations for specific minimum requirements (bio-based content, \\
& degradability) especially for plastics" \\
\hline
\end{tabular}


Table A12. Selected summary of questionnaire answers with gaps in current sustainability certification activities with emphasis on traceability of sustainability and certificates along the value chain.

\begin{tabular}{|c|c|}
\hline Identified Gap & Expert Interview Answer \\
\hline \multirow{6}{*}{$\begin{array}{l}\text { Traceability of sustainability and } \\
\text { certificates along the value chain }\end{array}$} & $\begin{array}{l}\text { Demand for "better traceability of sustainability information along } \\
\text { entire supply chain, performance also compared to non-bio" }\end{array}$ \\
\hline & $\begin{array}{l}\text { Demand for "Performance indicators; features related to health, origin } \\
\text { of biomass (made in.)" }\end{array}$ \\
\hline & $\begin{array}{l}\text { "Demand for criteria to express the value of local small value chains, } \\
\text { closed nutrient cycles, etc." }\end{array}$ \\
\hline & $\begin{array}{l}\text { "Use of databases transferring sustainability characteristics across } \\
\text { supply chain" }\end{array}$ \\
\hline & $\begin{array}{l}\text { "Use of objective analysis, e.g., remote sensing tool as proof of no } \\
\text { deforestation and transfer of information across supply chain with } \\
\text { better traceability tools" }\end{array}$ \\
\hline & $\begin{array}{l}\text { Demand for an "obligatory database to be publicly available for all } \\
\text { assessment/certification systems with detailed information about all } \\
\text { granted certificates and holders" }\end{array}$ \\
\hline
\end{tabular}

\section{Appendix D-Standards Landscape-Selected Examples}

Table A13. Standards landscape-Relevant standards in CEN/TR 16208.

\begin{tabular}{|c|c|c|c|c|c|}
\hline Acronym & Title & Sust & Envi & Soci & Econ \\
\hline ISO 26000 & Guidance on social responsibility & $\mathrm{x}$ & $\mathrm{x}$ & $\mathrm{x}$ & $\mathrm{x}$ \\
\hline NTA 8080 & Sustainability criteria for biomass for energy purposes & $\mathrm{x}$ & $\mathrm{x}$ & $\mathrm{x}$ & $\mathrm{x}$ \\
\hline ISO $1404 \mathrm{X}$ & Environmental management-Life cycle assessment (Series) & - & $x$ & - & - \\
\hline $\begin{array}{l}\text { VDI } 4431 \text { ISO } \\
14064\end{array}$ & $\begin{array}{l}\text { GHG-Part 1: Specification with guidance at the organization level } \\
\text { for quantification and reporting of GHG emissions and removals }\end{array}$ & - & $\mathrm{x}$ & $\mathrm{x}$ & - \\
\hline CEN/TR 15932 & $\begin{array}{l}\text { Plastics-Recommendation for... characterisation of biopolymers \& } \\
\sim \text { plastics }\end{array}$ & - & $\mathrm{x}$ & - & - \\
\hline ASTM D 7075 & Practice for Evaluating and Reporting Environ. Performance of BBP & $x$ & $x$ & - & - \\
\hline ASTM D6852 & Environmental Profile of Materials and Products & - & $x$ & - & - \\
\hline PAS 2050 & Specification for the assessment of the life cycle & - & $x$ & - & - \\
\hline BP X30-323 & General principles for an environ. communication & - & $x$ & - & - \\
\hline ISO 15380 & Lubricants, industrial oils and related products ... & - & $\mathrm{x}$ & - & - \\
\hline SS 155434 & Hydraulic fluids-Requirements and test methods & - & $\mathrm{x}$ & - & - \\
\hline SS 155470 & Lubricants, industrial oil and related products ... & - & $x$ & - & - \\
\hline NF U 52-001 & Biodegradable materials-Mulching products-Reg. \& test methods & - & $\mathrm{x}$ & - & - \\
\hline
\end{tabular}

Table A14. Standards landscape-Further examples.

\begin{tabular}{|c|c|c|c|c|c|}
\hline Acronym & Topic & Sust & Envi & Soci & Econ \\
\hline EN 16751 & Bio-based products-Sustainability criteria & $x$ & $x$ & $x$ & $x$ \\
\hline CEN/TR 16957 & Bio-based products-Guidelines for LCI for the EoL phase & $x$ & $x$ & - & - \\
\hline \multicolumn{6}{|c|}{ Standards in related areas } \\
\hline $\begin{array}{l}\text { ISO/FDIS } \\
34101-2\end{array}$ & $\begin{array}{l}\text { Sustainable and traceable cocoa beans-Part 2: Req. For performance } \\
\text { (related to econ., social, and environ. aspects) }\end{array}$ & $x$ & $x$ & $\mathrm{x}$ & $x$ \\
\hline
\end{tabular}




\section{References}

1. National Policy Strategy on Bioeconomy: Renewable Resources and Biotechnological Processes as a Basis for Food, Industry and Energy, 2014th ed.; Federal Ministry of Food and Agriculture: Berlin, Germany, 2014.

2. Delbrück, S. Future Opportunities and Developments in the Bioeconomy-A Global Expert Survey; German Bioeconomy Council: Berlin, Germany, 2018.

3. Staffas, L.; Gustavsson, M.; McCormick, K. Strategies and Policies for the Bioeconomy and Bio-Based Economy: An Analysis of Official National Approaches. Sustainability 2013, 5, 2751-2769. [CrossRef]

4. European Commission. Bio-Based Economy for Europe: State of Play and Future Potential Europe; Report on the European Commission's Public on-line Consultation; Publications Office of the European Union: Luxembourg, 2011.

5. Giuntoli, J.; Cristobal, J.; Parisi, C.; Ferrari, E.; Marelli, L.; Torres de Matos, C.; Gomez Barbero, M.; Rodriguez Cerezo, E. Bioeconomy Report 2016; JRC Scientific and Policy Report; Publications Office of the European Union: Luxembourg, 2017.

6. Du Pisani, J.A. Sustainable development-Historical roots of the concept. Environ. Sci. 2006, 3, 83-96. [CrossRef]

7. Wiersum, K.F. 200 years of sustainability in forestry: Lessons from history. Environ. Manag. 1995, 19, 321-329. [CrossRef]

8. Komives, K.; Jackson, A. Introduction to Voluntary Sustainability Standard Systems. In Voluntary Standard Systems; Schmitz-Hoffmann, C., Schmidt, M., Hansmann, B., Palekhov, D., Eds.; Springer: Berlin/Heidelberg, Germany, 2014; pp. 3-19.

9. FSC International. FSC Database. Available online: https://ic.fsc.org/en (accessed on 25 April 2018).

10. Kraxner, F.; Schepaschenko, D.; Fuss, S.; Lunnan, A.; Kindermann, G.; Aoki, K.; Dürauer, M.; Shvidenko, A.; See, L. Mapping certified forests for sustainable management-A global tool for information improvement through participatory and collaborative mapping. For. Policy Econ. 2017, 83, 10-18. [CrossRef]

11. Directive (EU) 2015/1513 of the European Parliament and of the Council of 9 September 2015 Amending Directive 98/70/EC Relating to the Quality of Petrol and Diesel Fuels and Amending Directive 2009/28/EC on the Promotion of the Use of Energy from Renewable Sources; European Union: Brussels, Belgium, 2015.

12. Mitchel, D. A Note on Rising Food Prices; The World Bank: Washington, DC, USA, 2008.

13. Searchinger, T.; Heimlich, R.; Houghton, R.A.; Dong, F.; Elobeid, A.; Fabiosa, J.; Tokgoz, S.; Hayes, D.; $\mathrm{Yu}, \mathrm{T}$.-H. Use of U.S. croplands for biofuels increases greenhouse gases through emissions from land-use change. Science 2008, 319, 1238-1240. [CrossRef] [PubMed]

14. Lin, J. Governing Biofuels: A Principal-Agent Analysis of the European Union Biofuels Certification Regime and the Clean Development Mechanism. J. Environ. Law 2012, 24, 43-73. [CrossRef]

15. Proposal for a Directive of the European Parliament and of the Council on the Promotion of the Use of Energy from Renewable Sources (Recast). COM/2016/0767 Final/2-2016/0382 (COD); European Commission: Brussels, Belgium, 2016.

16. van Dam, J.; Junginger, M.; Faaij, A.; Jürgens, I.; Best, G.; Fritsche, U. Overview of recent developments in sustainable biomass certification. Biomass Bioenergy 2008, 32, 749-780. [CrossRef]

17. Ladu, L.; Blind, K. Overview of policies, standards and certifications supporting the European bio-based economy. Curr. Opin. Green Sustain. Chem. 2017, 8, 30-35. [CrossRef]

18. Blind, K.; Petersen, S.S.; Riillo, C.A.F. The impact of standards and regulation on innovation in uncertain markets. Res. Policy 2017, 46, 249-264. [CrossRef]

19. M/491 Mandate Addressed to CEN, CENELEC and ETSI for the Development of European Standards and Technical Specifications and/or Technical Reports for Bio-Surfactants and Bio-Solvents in Relation to Bio-Based Product Aspects; European Commission: Brussels, Belgium, 2011.

20. M/492 Mandate Addressed to CEN, CENELEC and ETSI for the Development of Horizontal European Standards and other Standardisation Deliverables for Bio-Based Products; European Commission: Brussels, Belgium, 2011.

21. Mandate 53/2008 (CEN M/430) M/430 Mandate Addressed to CEN for the Development of European Standards and CEN Workshop Agreements for Bio-Polymers and Bio-Lubricants in Relation to Bio-Based Product Aspects; European Commission: Brussels, Belgium, 2008. 
22. Directive 2009/30/EC of the European Parliament and of the Council of 23 April 2009 Amending Directive 98/70/EC as Regards the Specification of Petrol, Diesel and Gas-Oil and Introducing a Mechanism to Monitor and Reduce Greenhouse Gas Emissions and Amending Council Directive 1999/32/EC as Regards the Specification of Fuel Used by Inland Waterway Vessels and Repealing Directive 93/12/EEC: FQD; European Commission: Brussels, Belgium, 2009.

23. Lewandowski, I. Securing a sustainable biomass supply in a growing bioeconomy. Glob. Food Secur. 2015, 6, 34-42. [CrossRef]

24. Majer, S.; Moosmann, D.; Sumfleth, B. STAR-ProBio Criteria and Indicator Database. 2017. Available online: http:/ / www.star-probio.eu/wp-content/uploads/2017/12/Star-ProBio_certification_criteria.xlsx (accessed on 15 March 2018).

25. Strauss, A.L.; Corbin, J.M. Grounded Theory: Grundlagen Qualitativer Sozialforschung; Beltz: Weinheim, Germany, 2010.

26. STAR-ProBio. STAR-ProBio Deliverable D7.1. Examination of Existing ILUC Approaches and Their Application to Bio-Based Materials; Unitelma Sapienza University: Rome, Italy, 2018.

27. DIN. DIN ISO 13065 Nachhaltigkeitskriterien für Bioenergie; DIN: Berlin, Germany, 2017.

28. D18 Committee. Guide for Set of Data Elements to Describe a Groundwater Site; Part One-Additional Identification Descriptors; ASTM International: West Conshohocken, PA, USA, 2004.

29. D18 Committee. Guide for Using the Seismic Refraction Method for Subsurface Investigation; ASTM International: West Conshohocken, PA, USA, 2011.

30. D18 Committee. Guide for Selection of Methods for Estimating Soil Loss by Erosion; ASTM International: West Conshohocken, PA, USA, 2012.

31. D20 Committee. Guide for Exposing and Testing Plastics that Degrade in the Environment by a Combination of Oxidation and Biodegradation; ASTM International: West Conshohocken, PA, USA, 2018.

32. Iriarte, L. Consistent Cross-Sectoral Sustainability Criteria E Indicators; European Commission: Brussels, Belgium, 2017.

33. Iriarte, L. Benchmark and Gap Analysis of Criteria and Indicators (CEI) for Legislation, Regulations and Voluntary Schemes at International Level and in Selected EU Member States: Main Report; European Commission: Brussels, Belgium, 2015.

34. Buchholz, T.; Luzadis, V.A.; Volk, T.A. Sustainability criteria for bioenergy systems: Results from an expert survey. J. Clean. Prod. 2009, 17, S86-S98. [CrossRef]

35. Pavlovskaia, E. Sustainability criteria: Their indicators, control, and monitoring (with examples from the biofuel sector). Environ. Sci. Eur. 2014, 26, 17. [CrossRef] [PubMed]

36. FAO. FAO's BEFS Approach at a Glance. Available online: http://www.fao.org/3/a-h0011e.pdf (accessed on 20 December 2017).

37. Majer, S.; Gröngröft, A.; Drache, C.; Braune, M.; Meisel, K.; Müller-Langer, F.; Naumann, K.; Oehmichen, K. Technische und Methodische Grundlagen der THG-Bilanzierung von Biodiesel, 1st ed.; DBFZ: Leipzig, Germany, 2015.

38. Naumann, K.; Oehmichen, K.; Remmele, E.; Thuneke, K.; Schröder, J.; Zeymer, M.; Zech, K.; Müller-Langer, F. Monitoring Biokraftstoffsektor, 3rd ed.; DBFZ: Leipzig, Germany, 2016.

39. Oehmichen, K.; Naumann, K.; Drache, C.; Postel, J.; Braune, M.; Gröngröft, A.; Majer, S.; Meisel, K.; Müller-Langer, F. Technische und Methodische Grundlagen der THG-Bilanzierung von Biomethan, 1st ed.; DBFZ: Leipzig, Germany, 2015.

40. Bentsen, N.S. Carbon debt and payback time-Lost in the forest? Renew. Sustain. Energy Rev. 2017, 73, 1211-1217. [CrossRef]

41. Bovari, E.; Lecuyer, O.; Mc Isaac, F. Debt and damages: What are the chances of staying under the $2{ }^{\circ} \mathrm{C}$ warming threshold? Int. Econ. 2018. [CrossRef]

42. Finkbeiner, M. Indirect land use change-Help beyond the hype? Biomass Bioenergy 2014, 62, $218-221$. [CrossRef]

43. Laborde, D. Assessing the Land Use Change Consequences of European Biofuel Policies: Final Report; IFPRI: Washington, DC, USA, 2011.

44. Mohr, A.; Beuchelt, T.; Schneider, R.; Virchow, D. Food security criteria for voluntary biomass sustainability standards and certifications. Biomass Bioenergy 2016, 89, 133-145. [CrossRef] 
45. Mohr, A.; Beuchelt, T.; Schneider, R.; Virchow, D. A Rights-Based Food Security Principle for Biomass Sustainability Standards and Certification Systems; ZEF: Bonn, Germany, 2015.

46. Peters, D. Methodologies for the Identification and Certification of Low ILUC Risk Biofuels; Wageningen University \& Research: Wageningen, the Netherlands, 2016.

47. Roundtable on Sustainable Biomaterials. RSB Low iLUC Risk Biomass Criteria and Compliance Indicators, 4 th ed.; Roundtable on Sustainable Biomaterials: Berlin, Germany, 2015.

48. Marazza, D.; Merloni, E.; Compagnoni, L. Examination of Existing iLUC Approaches and Application to Bio-Based Materials: Star-ProBio Deliverable 7.1; European Commission: Bologna, Italy, 2018.

49. Ahlgren, S.; Di Lucia, L. Indirect land use changes of biofuel production-A review of modelling efforts and policy developments in the European Union. Biotechnol. Biofuels 2014, 7, 35. [CrossRef] [PubMed]

50. Scarlat, N.; Dallemand, J.-F.; Monforti-Ferrario, F.; Nita, V. The role of biomass and bioenergy in a future bioeconomy: Policies and facts. Environ. Dev. 2015, 15, 3-34. [CrossRef]

51. Van Lancker, J.; Wauters, E.; van Huylenbroeck, G. Managing innovation in the bioeconomy: An open innovation perspective. Biomass Bioenergy 2016, 90, 60-69. [CrossRef]

52. Selbmann, K.; Pforte, L. Evaluation of Ecological Criteria of Biofuel Certification in Germany. Sustainability 2016, 8, 936. [CrossRef]

53. CEN/TC 411 Bio-Based Products-Biobasedeconomy. Available online: http:/ /www.biobasedeconomy.eu/ centc-411-bio-based-products / (accessed on 29 June 2018).

54. IEC—SMB: Standardization Management Board > Technical Advisory Committees. Available online: http: / / www.iec.ch/dyn/www /f?p=103:59:0::FSP_ORG_ID,FSP_LANG_ID:3228,25 (accessed on 29 June 2018).

55. Sherwood, J.; de Bruyn, M.; Constantinou, A.; Moity, L.; McElroy, C.R.; Farmer, T.J.; Duncan, T.; Raverty, W.; Hunt, A.J.; Clark, J.H. Dihydrolevoglucosenone (Cyrene) as a bio-based alternative for dipolar aprotic solvents. Chem. Commun. (Camb. Engl.) 2014, 50, 9650-9652. [CrossRef] [PubMed]

56. Carus, M.; Dammer, L.; Puente, Á.; Raschka, A.; Arendt, O. Bio-Based Drop-In, Smart Drop-In and Dedicated Chemicals; Nova-Institut für Politische und Ökologische Innovation GmbH: Hürth, Germany, 2017.

57. Communication from the Commission to the European Parliament, the Council, the European Economic and Social Committee and the Committee of the Regions. Closing the Loop-An EU Action Plan for the Circular Economy: COM(2015) 614 Final; European Commission: Brussels, Belgium, 2015.

58. nova-Institut GmbH. Bio-Based Polymers Worldwide: Ongoing Growth Despite Difficult Market Environment-Bio-Based News-The Portal for Bio-Based Economy \& Industrial Biotechnology. 2018. Available online: http://news.bio-based.eu/bio-based-polymers-worldwide-ongoing-growth-despitedifficult-market-environment/ (accessed on 27 April 2018).

59. Grand Review Research. Biolubricants Market Size to Reach $\$ 2.92$ Billion by 2024. Available online: https:/ / www.grandviewresearch.com/press-release/bio-lubricants-market (accessed on 27 April 2018). 